\title{
Representative Values of Icing-Related Variables Aloft in Freezing Rain and Freezing Drizzle
}

Richard K. Jeck

March 1996

DOT/FAA/AR-TN95/119

This document is available to the public through the National

Technical Information Service (NTIS), Springfield, Virginia 22161.

U.S. Department of Transportation

Federal Aviation Administration 


\section{NOTICE}

This document is disseminated under the sponsorship of the U.S. Department of Transportation in the interest of information exchange. The United States Government assumes no liability for the contents or use thereof. The United States Government does not endorse products or manufacturers. Trade or manufacturer's names appear herein solely because they are considered essential to the objective of this report. 


\begin{tabular}{|c|c|c|}
\hline $\begin{array}{l}\text { 1. Report No. } \\
\text { DOT/FAA/AR-TN95/119 }\end{array}$ & 2. Government Accession No. & 3. Recipient's Catalog No. \\
\hline \multicolumn{2}{|l|}{ 4. Title and Subtitle } & $\begin{array}{l}\text { 5. Report Date } \\
\text { March } 1996\end{array}$ \\
\hline \multicolumn{2}{|c|}{$\begin{array}{l}\text { REPRESENTATIVE VALUES OF ICING-RELATED VARIABLES ALOFT IN } \\
\text { FREEZING RAIN AND FREEZING DRIZZLE }\end{array}$} & $\begin{array}{l}\text { 6. Performing Organization Code } \\
\text { AAR-421 }\end{array}$ \\
\hline \multicolumn{2}{|l|}{ 7. Author(s) } & $\begin{array}{l}\text { 8. Performing Organization Report No. } \\
\text { DOT/FAA/AR-TN95/119 }\end{array}$ \\
\hline \multirow{2}{*}{\multicolumn{2}{|c|}{$\begin{array}{l}\text { 9. Performing Organization Name and Address } \\
\text { Airport and Aircraft Safety } \\
\text { Research and Development Division } \\
\text { FAA Technical Center } \\
\text { Atlantic City International Airport, NJ } 08405\end{array}$}} & 10. Work Unit No. (TRAIS) \\
\hline & & 11. Contract or Grant No. \\
\hline \multirow{2}{*}{\multicolumn{2}{|c|}{$\begin{array}{l}\text { 12. Sponsoring Agency Name and Address } \\
\text { U.S. Department of Transportation } \\
\text { Federal Aviation Administration } \\
\text { Office of Aviation Research } \\
\text { Washington, D.C. } 20591\end{array}$}} & $\begin{array}{l}\text { 13. Type of Report and Period Covered } \\
\text { Technical Note }\end{array}$ \\
\hline & & 14. Sponsoring Agency Code \\
\hline
\end{tabular}

15. Supplementary Notes

16. Abstract

Radiosonde and surface observations in freezing rain (ZR) and freezing drizzle (ZL), and a limited number of aircraft measurements in ZR, have been examined for information on the magnitude and altitude dependence of meteorological variables associated with aircraft icing in these conditions. The variables include temperature aloft, humidity (clouds), and windshear from the radiosondes; surface temperatures, ceiling heights, precipitation type and amount from the surface observations; and temperature, dropsize, rainwater concentration, and icing rate from the instrumented aircraft. These and other data are used here to arrive at tentative maximum and representative values of these variables. To overcome the inadequacy of median volume diameter (MVD) as a measure of dropsize for these large droplet conditions, a convention for reporting the ZR or ZL water concentration over a few coarse dropsize intervals is proposed.

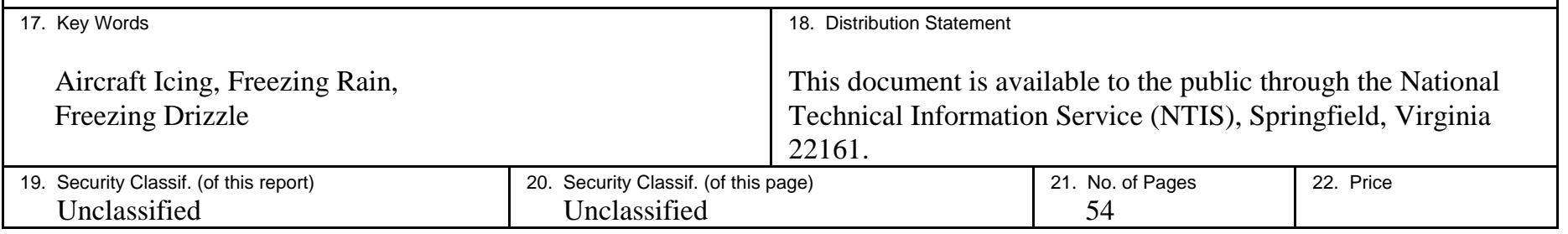




\section{ACKNOWLEDGMENT}

The author is indebted to colleague Dr. James T. Riley for working up the University of North Dakota aircraft data for computer analysis and display in time for this report. 


\section{TABLE OF CONTENTS}

Page

EXECUTIVE SUMMARY

ix

BACKGROUND

1

RESULTS 2

Terms and Definitions $\quad 2$

Freezing Rain $\quad 3$

Freezing Drizzle $\quad 4$

Elevated Freezing Rain $\quad 6$

Where Does Elevated ZR Occur? $\quad 6$

Elevated Freezing Drizzle $\quad 6$

Early Indications $\quad 6$

$\begin{array}{ll}\text { The Roselawn Accident } & 7\end{array}$

Understanding Elevated ZL $\quad 8$

How Often Does Elevated ZL Occur $\quad 8$

Where Does Elevated ZL Occur?

General Observations from Aircraft Measurements 99

ZR Measurements by the University of North Dakota (UND) 9

The Canadian Atmospheric Environment Service Projects 10

Flying in Freezing Rain 11

Low-Lying Freezing Rain 11

Elevated Freezing Rain 11

Flying in Freezing Drizzle $\quad 11$

Low-Lying Drizzle Clouds $\quad 12$

Elevated Freezing Drizzle $\quad 12$

Existing Design Values 12

Civil $\quad 12$

$\begin{array}{ll}\text { Military } & 13\end{array}$ 
$\begin{array}{ll}\text { Available Data for Freezing Rain } & 14\end{array}$

$\begin{array}{ll}\text { Rain Rates } & 14\end{array}$

Rainwater Concentration (RWC) 14

Droplet Sizes $\quad 15$

Air Temperature 16

Depth of Freezing Rain Layers $\quad 17$

Horizontal Extent or Exposure Time $\quad 17$

Available Data for Freezing Drizzle 17

$\begin{array}{lr}\text { Droplet Sizes } & 18\end{array}$

Alternates to the MVD 19

Rain Rate $\quad 20$

Drizzle Water Concentration (DWC) 21

Horizontal Extent or Exposure Time $\quad 21$

Developing New Design Criteria and Test Conditions for Freezing Rain and Freezing Drizzle $\quad 21$

SUMMARY AND CONCLUSIONS 22

REFERENCES 23 


\section{LIST OF FIGURES}

Figure

Page

1 Frequency of Freezing Rain or Freezing Drizzle Over the United States

2 Schematic Representation of Freezing Rain Conditions

3 Schematic Representation of a Warm Front

$4 \quad$ Sample Temperature Profiles for Freezing Rain

$5 \quad$ Magnified Images of Freezing Drizzle Droplets

6 Example of Midlevel Cloud Layer That May Contain Freezing Drizzle

$7 \quad$ Freezing Rain at Kansas City, on February 1, 1990

8 Purported 99 Percent Limits to RWC and "Droplet Diameter" as a Function of Surface Temperature in Freezing Rain

9 Frequency Distribution of Cold Rain Rates in New England

10 Frequency Distribution of Surface Air Temperature in Freezing Rain in the Northeastern United States

11 Examples of Natural Cloud and Drizzle Dropsize Distributions Compared to Tanker Spray 


\section{LIST OF TABLES}

Table

Page

1 Types of Data Available for Freezing Rain/Drizzle Conditions

2 Statistics on Type of Freezing Precipitation and Accompanying Vertical

Temperature Structure at Selected Locations

3 Some Airborne Measurements of Freezing Rain and Freezing Drizzle

4 Available Freezing Rain Data from University of North Dakota Instrumented

Aircraft

5 Temperatures and Depths of the Freezing Rain or Freezing Drizzle Layers from Radiosonde Measurements at Selected Locations

6 Examples of the Contribution of "Large Droplets" to the Overall LWC and MVD in a Natural Cloud Containing Drizzle

7 Proposed LWC Versus Dropsize Reporting Scheme for Drizzle and Freezing Rain

8 Possible First-Priority Design Variables 


\section{EXECUTIVE SUMMARY}

Freezing rain and freezing drizzle (meteorological abbreviations are ZR and ZL, respectively) have been implicated in a number of recent commuter aircraft accidents and incidents. One notable example was the fatal crash of a commuter flight on October 31, 1994, near Roselawn, Indiana. Others include cases of uncommanded pitchovers of certain commuter aircraft during landing approach with ice on the tail section of the aircraft-a situation that has been given the name Ice Contaminated Tailplane Stall (ICTS).

Little has been known statistically about the details of ZR and ZL conditions aloft, because the few previous studies have concentrated on surface observations and near-surface effects of such conditions. But fortunately, one of these studies recently tabulated the dates, times, and locations of nearly a thousand ZR and ZL episodes at major airports in the U.S. over a 24-year period. Eighteen of these airports are located at standard radiosonde launch sites. These archived radiosonde data were retrieved for this study to examine the vertical distribution and characteristics of these known ZR and ZL cases. In addition, inflight data from several rare penetrations of ZR, ZL conditions by an instrumented aircraft have been obtained from the University of North Dakota. This has helped to improve the understanding of $\mathrm{ZR}$ and $\mathrm{ZL}$ conditions aloft. The benefits could include better icing forecasts, better flight planning, and increased understanding and awareness of ZR and ZL conditions by pilots, dispatchers, and controllers alike.

Most ZR or ZL occurrences reported at the surface are accompanied by low ceilings. The ratio of ZR to ZL differs markedly among some sites; but overall, ZL is reported for about 60 percent of the cases compared to 40 percent for ZR. Assuming that the observers have correctly distinguished ZL from $\mathrm{ZR}$, this indicates that the drizzle phenomenon is more common than previously thought, at least in low ceiling conditions involving freezing precipitation.

From the radiosonde data it is found that ZR conditions can extend up to 7000-ft above ground level (AGL) at some locations, and temperatures can range down to $-11^{\circ} \mathrm{C}$. Aircraft measurements have documented ZL up to $12,500-\mathrm{ft}$ AGL at temperatures down to $-11^{\circ} \mathrm{C}$.

As a result of the crash near Roselawn, Indiana, in October 1994, the radiosonde data used for this report have been searched for evidence of cloud layers aloft that could produce "elevated" freezing drizzle similar to that suspected of causing the accident. Adequately deep supercooled cloud layers in the 5000- to 17,000-ft AGL altitude range are inferred in about 30 percent of the cases, but there is no direct evidence from the radiosondes about how many of these cloud layers may be producing ZL.

From the few available passes of an instrumented aircraft in ZR conditions at several locations, rainwater concentrations (RWC) of 0.1 to $0.3 \mathrm{~g} / \mathrm{m}^{3}$ were documented along with typical RMVD's (raindrop median volume diameters) of about $1 \mathrm{~mm}$. These are consistent with other indirect estimates for these variables. Onboard ice detectors registered icing rates up to $15 \mathrm{~mm} / \mathrm{hr}(5 / 8$ $\mathrm{inch} / \mathrm{hr}$ ). This means that during a 15-minute approach and landing sequence, an aircraft could accumulate up to $4 \mathrm{~mm}$ (5/32 inch) of glaze ice on the airframe in the observed ZR conditions. 
The small amounts of data available so far on ZL suggest representative drizzle water concentrations (DWC) of about $0.1 \mathrm{~g} / \mathrm{m}^{3}$ distributed over the drizzle-dropsize range of 50-500 $\mu \mathrm{m}$. Maximum DWC's have been reported up to $0.3 \mathrm{~g} / \mathrm{m}^{3}$ or more in clouds.

Finally, a new convention is proposed here for reporting and specifying water concentrations and dropsizes for freezing rain and drizzle. The proposal is to divide the water concentrations into five standardized dropsize intervals over the applicable dropsize ranges of 50 to $500 \mu \mathrm{m}$ for drizzle and 0.5 to $4 \mathrm{~mm}$ for freezing rain. This is adequate resolution for aircraft icing purposes, and it provides a more useful way to display, compare, and evaluate results than either the graphical dropsize distributions or simple RWC and MVD values. The method is convenient for use with natural ZR and ZL conditions, tanker and wet wind tunnel sprays, and computer simulations. 


\section{BACKGROUND}

Freezing rain and freezing drizzle (meteorological abbreviations are ZR and ZL, respectively) ${ }^{1}$ have been implicated in a number of recent commuter aircraft accidents and incidents. One notable example was the fatal crash of a commercial airline flight on October 31, 1994, near Roselawn, Indiana. Others include cases of uncommanded pitchovers of certain commuter aircraft during approach with ice on the tail section of the aircraft — a situation that has been given the name Ice Contaminated Tailplane Stall (ICTS).

The Flight Safety Research Branch of the Federal Aviation Administration (FAA) Technical Center has been undertaking a long-term research project to improve the understanding of the icing environment faced by aircraft in flight above the freezing level. One goal has been to update, if necessary, the engineering design values of atmospheric variables associated with icing conditions. One type of icing condition for which adequate measurements have been lacking is that of ZR and ZL.

The general features of freezing rain and freezing drizzle have long been known, but no statistics have been compiled on the details aloft such as the extreme and average temperatures in freezing precipitation layers, ceiling heights, the presence and depth of any supercooled cloud layers, and the vertical extent of ZR and ZL, for example. Direct measurements of other important variables such as rainwater concentrations (RWC), dropsizes, and icing rates are rare and scattered. Only two major statistical studies [2,3] have been reported at all, and both of these concentrated on surface observations and surface effects.

Geographically, it is known from these surface weather observations that ZR and ZL occur mainly in central and eastern North America (figure 1) and in Northern Europe. Nevertheless, ZR and ZL are infrequent, even in these locations. Typically ZR or ZL occurs 4 percent of the time or less in North America during the colder seasons and 1 percent of the time or less in Europe. Because of the possibly of drastic effects, however, flight in ZR and ZL is normally avoided even by aircraft equipped with anti-icing or deicing devices.

Sporadic research reports over the years have gradually accumulated evidence that freezing drizzle is more common than previously realized and that it forms surprisingly often in entirely subfreezing conditions. No statistics have been collected on this either, but it has important implications for inflight icing.

Data which are essential for the design or testing of aircraft for flight in ZR or ZL include representative and probable extreme values of the rainwater concentration (RWC), air temperature, and dropsizes. Ordinarily, measurements of these variables would be obtained from instrumented aircraft sent to fly in the conditions of interest. Because of the difficulty of flying in, or operating measuring devices in ZR or ZL, only a small number of inflight measurements

\footnotetext{
${ }^{1}$ These two types of precipitation will often be referred to throughout this report by the meteorological reporting symbols, ZR and ZL.
} 
have been made until recently. Except for one report [1] discussed below, and a few encounters by research aircraft from the Universities of North Dakota and Wyoming, no other airborne RWC and dropsize measurements were available in time for this report.

As a result, the research so far has had to rely mainly upon surface weather observations and radiosondes (instrumented balloon soundings) for information on ZR and ZL conditions aloft. Recent advances in doppler weather radar techniques hold some promise for the future. The information potentially available from all these various sources is summarized in table 1 .

An important recent study was the compilation of ZR and ZL occurrences and durations at a hundred or so airports in the United States over a 25-year period from about 1962 to 1987 [3]. Eighteen of the airports were also at or near the sites of synoptic radiosonde stations. Although the study was based only on surface weather reports, the author fortunately obtained the dates and times of occurrence of the ZR and ZL conditions at each airport. This allowed an easy retrieval of archived radiosonde data for the 18 airports. More than 700 radiosonde ascents were identified in this way, where ZR or ZL was present at the time of the ascent. These data are currently being analyzed to give previously unavailable statistics on conditions above the surface during freezing rain and freezing drizzle. In particular, the depths and extreme temperatures in the freezing layers and warm layers aloft are revealed by the radiosondes. Cloud layers can also be deduced from the onboard humidity sensor. Table 2 gives some preliminary results which show a marked variation in the relative frequency of freezing precipitation type and vertical temperature structure at different locations in the United States.

This will improve the understanding of ZR and ZL conditions aloft. The benefits could include better icing forecasts, better flight planning, and increased understanding and awareness of ZR and ZL conditions by pilots, dispatchers, and controllers alike.

\section{RESULTS}

\section{TERMS AND DEFINITIONS.}

Recently some new terms have been informally introduced to describe these icing conditions that involve dropsizes larger than ordinary cloud droplets covered by FARs 25 and 29, Appendix C [28]. These new terms are "large droplets," "supercooled drizzle droplets" (SCDD), and "supercooled large droplets" (SLD). There are no formal definitions of these terms and they are often used interchangeably. Generally they are used to describe droplets larger than 40 or $50 \mu \mathrm{m}$ in diameter. Such droplets are often said to be outside the range of FARs 25 and 29, Appendix C 
because the liquid water concentration versus droplet median-volume diameter (LWC vs. MVD) envelopes $^{2}$ of FARs 25 and 29, Appendix C stop at an MVD of 40 or $50 \mu \mathrm{m}$.

The existence of several terms to describe the same thing can lead to confusion. It implies that there are some distinctions where there may really be none. Therefore, it is recommended here that in order to avoid an unnecessary proliferation of terms, the conventional terms freezing rain and freezing drizzle be used exclusively. These terms already apply to droplets that are distinguished by their large sizes. There are really only two means of formation for these large droplets anyway-the coalescence process and the melting snow process (see further discussions of $\mathrm{ZR}$ and $\mathrm{ZL}$ in the following paragraphs). Drizzle and rain usefully connote differences in rain rates too.

\section{FREEZING RAIN.}

A distinction is made between $\mathrm{ZR}$ and $\mathrm{ZL}$ because of the differences in the formation mechanisms and the resulting differences in dropsizes and rain rates.

Freezing rain results when snowflakes fall into a warm $\left(\mathrm{T}>0^{\circ} \mathrm{C}\right)$ layer aloft, melt into raindrops, and then fall through a subfreezing layer of air again before reaching the ground. This is illustrated schematically in figure 2. The only difference between freezing rain and ordinary stratiform (widespread, steady, nonfreezing) rain is the presence of a subfreezing layer from ground level up to perhaps a few thousand feet in the case of freezing rain. Ordinarily, air temperatures rise steadily with decreasing altitude and therefore temperatures below the $0^{\circ} \mathrm{C}$ level aloft will ordinarily be warmer than freezing. But freezing rain requires a reversal in the temperature profile somewhere below the melting layer such that subfreezing temperatures are again present at or above ground level. This can occur in connection with a warm front (figure 3 ) when warm air overruns a subfreezing layer of air already in place.

The warm layer aloft is a well-known feature which pilots are taught to use in order to escape inadvertent encounters with freezing rain in flight. The seemingly counter-intuitive rule of thumb is to climb to warmer temperatures.

Raindrops are essentially melted snowflakes, so the raindrop sizes depend initially on the sizes of the melting snowflakes. The raindrops may grow or shrink on their way to earth. They may grow somewhat by sweeping up additional cloud droplets if the raindrops fall through an intervening cloud layer. They may also shrink due to partial or total evaporation while falling through cloudless air. Any droplets that are several millimeters in diameter may also split in two due to aerodynamic forces during their fall. The rain rate depends mainly on the snowfall rate at the melting level and on any effects of evaporation. The resulting dropsize distribution is

\footnotetext{
${ }^{2}$ This association of an individual droplet diameter with the upper MVD limit of FARs 25 and 29, Appendix C can be misleading. This is because the MVD actually represents a wider dropsize spectrum that usually extends to diameters at least 50 percent larger than the MVD itself. For an MVD of $50 \mu \mathrm{m}$, for example, this means that droplets as large as 75 $\mu \mathrm{m}$ or more in diameter are still covered by FARs 25 and 29, Appendix C.
} 
generally a continuum from several millimeters down to tens of microns in diameter. Thus, the rain dropsize distribution includes droplets in the drizzle size range (50 to $500 \mu \mathrm{m})$ too. It is even possible that partial evaporation may sometimes reduce the rain drops to drizzle size before they reach the ground. In any case, most of the mass will be in the larger sizes remaining.

\section{FREEZING DRIZZLE.}

Contrary to the rain process, drizzle develops totally within a liquid droplet cloud layer when the conditions are right. The melting snow process is not involved and a "warm" layer is often absent. Drizzle is most familiar as experienced at ground level, where a "mist" of lightly falling droplets is descending from low clouds above. But drizzle is not confined to the region below clouds-it continues on up into and throughout the vertical extent of the cloud layer where it is being formed. Drizzle droplets may even be somewhat larger and more numerous in the cloud than below where partial or near total evaporation can reduce the sizes and numbers of the droplets on their way down.

Theoretically, if given enough time, some drizzle-sized droplets can eventually develop in any cloud that lasts long enough, is deep enough, and which contains enough condensed water. This process involves the gradual growth of some of the ordinary cloud droplets to a diameter of 30 $\mu \mathrm{m}$ or so until they begin to settle. Then they begin to collide and coalesce with other droplets on their way down through the cloud as they grow to drizzle droplet size (about 50 to $500 \mu \mathrm{m}$ or so). This is found to be a slow and inefficient process, which is estimated to require at least two hours of uninterrupted cloud droplet growth after cloud formation just to get the process started [4]. Nevertheless, observations indicate that drizzle can form in layer clouds that meet the following requirements:

- The cloud layer lasts longer than two hours, at least.

- $\quad$ The cloud layer is at least $1000 \mathrm{ft}(0.3 \mathrm{~km})$ deep.

- $\quad$ Temperatures everywhere within the cloud are warmer than about $-12^{\circ} \mathrm{C}$ so that highly competitive ice crystals are less likely to be present.

The deeper the cloud the larger and more numerous the settling drizzle droplets can become due to more time and more droplets with which they can collide. Politovich [5] and others have also pointed out that some kind of upslope motion (orographic or warm frontal) is needed to induce new condensation and drive the continual cloud droplet formation and growth. This is necessary if the cloud layer is to be replenished or maintained against the gradual removal of cloud droplets and water by the drizzle falling out of the cloud.

Even so, the resulting amount of drizzle may be insignificant for aircraft icing unless something happens to greatly speed up the process. 
It is known that two other mechanisms can enhance drizzle production by promoting the quick and continual growth of ordinary droplets into the $30 \mu \mathrm{m}$ range where they can start the drizzle production process. One such mechanism is the presence of relatively large (10 $\mu \mathrm{m}$ or so) microscopic salt particles in the air where the cloud is forming. This happens frequently in oceanic coastal areas where whitecaps and surf spray inject saltwater droplets into the air. The smaller droplets evaporate and leave a residual aerosol of microscopic salt particles. This can be easily seen as a whitish haze all along the beach zone. Cloud droplets always form on submicron hygroscopic particles (called cloud condensation nuclei) anyway, but the presence of unusually large nuclei is known to result in unusually large cloud droplets. This is why drizzle is more often observed under low cloud conditions in coastal areas than anywhere else. But large salt nuclei seldom reach very far inland or rise to the vicinity of the 10,000-ft $(3-\mathrm{km})$ level where the elevated freezing drizzle clouds of interest are occurring. Therefore, some other mechanism must be at least occasionally active inland and at the altitudes of interest in order for large numbers and sizes of drizzle drops to be present.

The other mechanism is thought to be turbulence. Almeida [6] and others have shown theoretically that sufficiently intense in-cloud turbulence can promote the growth of droplets into the $30 \mu \mathrm{m}$ size and enhance the subsequent collision and coalescence of these droplets into drizzle [7]. This suggests that large droplets can be expected to occur widely, geographically. Warm fronts and turbulence are common and indeed drizzle is sometimes recorded at surface observing sites in association with warm front arrivals in the winter. Thus, there are some statistics available for drizzle at the surface, but it is not known how often it occurs at aircraft holding altitudes of 5000- to 15,000-ft AGL, for example.

Based on some numerical simulations and on comparisons with experimental evidence, Pobanz et al. [8] have postulated some minimum wind-shear (turbulence) conditions that must be met in order for drizzle to be promoted in cloud layers. Specifically, they propose that a definite windshear layer must be present at the top of the cloud layer and that the wind shear strength be at least $0.02 \mathrm{~m} / \mathrm{sec}$ per meter of height. In addition, the bulk Richardson number (Ri) computed across the shear layer must be less than unity. The bulk Richardson number is taken as a measure of the wind-shear-induced mixing, and $\mathrm{Ri}<1.0$ is sufficient to maintain turbulence. In any case, coalescence in stratiform clouds generally cannot generate drops as large as those that can result from melting snow flakes. Hence, drizzle drops are typically smaller than $500 \mu \mathrm{m}$ in diameter. 


\section{ELEVATED FREEZING RAIN.}

Freezing rain (ZR) and freezing drizzle (ZL) have been conventionally regarded as a ground-level phenomenon or at least confined to a shallow layer of frigid air above the ground during the winter season in some geographic regions. These freezing precipitation layers were previously thought to extend no more than five thousand feet or so above ground, as indicated in figure 4. Only recently has it been realized that both ZR and ZL may occur in elevated layers at heights up to $10,000 \mathrm{ft}(3 \mathrm{~km})$ or more AGL. In the warm seasons both ZL and ZR can occur even higher in vigorous convective clouds.

\section{WHERE DOES ELEVATED ZR OCCUR?}

Stratiform Clouds-Radiosonde measurements [13] suggest that elevated freezing rain layers may be possible at heights up to $11,000 \mathrm{ft}$ over England. In the winter half year, these freezing layers were concentrated below $5000 \mathrm{ft}(1.5 \mathrm{~km})$. During the summer half year, freezing layers (associated with possible ZR or ZL conditions aloft) still occurred and were concentrated between about 4000 and $9000 \mathrm{ft}$. The same study shows that there are regional differences though. Freezing layers associated with ZR over the British Isles are more likely to be elevated (2000- to 5000-ft above sea level (ASL)), whereas in Scandinavia the freezing layers are more frequently based at ground level.

Convective Clouds-It is known that worse icing conditions can occur at higher altitudes in deep, vigorously growing convective clouds or thunderstorms in summer-like conditions. Changnon et al. [15] report that for large, growing convective clouds in Illinois, "Typical incloud results at $-10^{\circ} \mathrm{C}$ reveal multiple updrafts that tend to be filled with large amounts of supercooled drizzle and raindrops." This means that aircraft penetrating the cores of these clouds in the 0 to $-20^{\circ} \mathrm{C}$ range can expect to encounter intense bursts of ZR or ZL too. It is not known how long these encounters can last, but because these clouds are usually of limited horizontal extent, the ZR or ZL is not expected to last as long as may be possible in stratiform clouds. Nevertheless, the windshield may ice over more than usual and prompt the flight crew to report severe icing conditions.

Wherever the freezing level is high enough, there may be ample warm air below in which an aircraft can melt off any ice that it may have accumulated at higher altitudes. But it may not have been realized that an aircraft may irrecoverably lose control due to ice accumulations aloft, even though warm air exists at lower altitudes as it did in the Roselawn case. In the latter situation, the freezing level in the area ranged from about $3000 \mathrm{ft}(1 \mathrm{~km})$ to about $7000 \mathrm{ft}(2 \mathrm{~km})$ so that warm air was available for melting off the ice had the aircraft not lost complete control.

\section{ELEVATED FREEZING DRIZZLE.}

EARLY INDICATIONS. It has long been known that drizzle can readily form in low, warm, stratiform clouds at least $1000 \mathrm{ft}$ thick in oceanic air masses. Dropsize measurements from instrumented aircraft flights in these clouds have been reported at least as far back as 1952 [4]. But until recently, large droplets indicative of elevated ZL in winter stratiform clouds were 
reported only occasionally [9-11]. All of these authors pointed out the potential significance for aircraft icing. Lewis noted the high collection efficiencies of large drops and that drops larger than $35 \mu \mathrm{m}$ or so would probably be reported by pilots as freezing rain because of a similar appearance on the windshield. Jeck observed small concentrations of large droplets below some winter stratiform clouds and pointed out that helicopters flying below winter clouds to maintain visibility and to avoid icing may still experience some icing from these unexpected, large droplets.

Although these large droplets were indeed noticed by the pilots as "rain" or "moisture" on the windshield, they had no unusual effect on the large research aircraft (Lockheed C-121). The first researchers to document performance degradations on an aircraft due to flight in ZL were Sand et al. [11] and Cooper et al. [12]. These were flights during cloud seeding experiments along the Sierra Nevada upslopes in California. They found that flight through these elevated ZL conditions could cause dramatic increases in drag due to the ZL droplets forming a thin but rough accumulation of ice under the wings.

With interest in ZR and ZL heightened among aviation-interested meteorologists and cloud physics research groups, the Canadians renewed their attention to ZR and ZL during recent field studies of storms and icing conditions in the Newfoundland coastal region. Indeed, at least two ZL episodes near 10,000-ft AGL were found and investigated by Cober et al. [14]. They reported that these elevated ZL cases were the "most severe icing environment encountered" during the field study. In two of the four ZL cases, the ZL caused "a rapid accumulation of ice on the pilot's window." This prompted the pilot to quickly get out of the icing conditions, usually by climbing in altitude. Figure 5 illustrates one of these cases.

THE ROSELAWN ACCIDENT. Evidence was slowly mounting that elevated ZL was occasionally out there, but it seemed hard to find. It was known that sometimes there were quite noticeable, possibly serious effects on the performance of some aircraft if they encountered it and lingered in it. But these conditions had been found only after searching in upslope clouds along the Sierra Nevada mountains in California, occasionally in the Denver area, and perhaps more frequently, recently in the Canadian Atlantic provinces. The documented cases also appeared to be confined to relatively shallow layers and limited horizontal extents. So the known cases were rare, remote, and locally confined. Therefore, it seemed unlikely that any aircraft simply transiting through an area of elevated ZL would be bothered much by it.

That was until the fatal accident with the ATR-72 commuter aircraft near Roselawn, Indiana, on October 31, 1994. At this writing, it has not been definitely proven that elevated ZL was present and that it produced the icing which caused this aircraft to roll out of control and crash. But circumstantial evidence and the slowly accumulated knowledge about elevated ZL conditions strongly suggest that this was the case.

The investigation of the accident points to a number of factors combining at the same time to result in the accident. The aircraft was in a holding pattern for thirty minutes and apparently circling at the exact height and location of one of these elevated ZL layers. If the aircraft were 
holding a few thousand feet higher or lower or if it were just passing through once on its way to a landing, the suspected ice accumulation and the accident probably would not have occurred. Other factors, such as the darkness which hindered the visual observation of any ice buildup, the use of the autopilot during the thirty-minute hold, and the retraction of the flaps after the icing exposure all conspired toward permitting the accident to happen.

UNDERSTANDING ELEVATED ZL. Now that there is practical evidence that elevated ZL can indeed be a deadly hazard, more needs to be learned about its frequency and conditions of occurrence and how to recognize and forecast its presence.

How Often Does Elevated ZL Occur? For an earlier purpose of obtaining statistics on the vertical extent and the temperatures involved in low-altitude ZR conditions, about 700 radiosonde (raob) records were obtained from the National Climatic Data Center (the weather records archives) in Asheville, North Carolina. These records were exclusively for cases where the radiosonde is known to have ascended through $\mathrm{ZR}$ or ZL conditions at the location of the radiosonde launching site.

These soundings have since been examined for any elevated, turbulent, supercooled cloud layers that meet the Pobanz, Marwitz, and Politovich requirements [8] mentioned earlier. Although about a third of these raobs indicate the presence of supercooled cloud layers covering part of the altitude interval between $5000 \mathrm{ft}(1.5 \mathrm{~km})$ and 15,000 $\mathrm{ft}(4.5 \mathrm{~km})$, the proposed wind shear and Richardson number requirements are seldom met. This suggests that although significant aircraft icing from ordinary supercooled clouds may be present in these layers and only rarely are conditions right for the enhanced formation of elevated freezing drizzle according to the requirements of Pobanz et al. One case where the proposed wind shear requirements appear to be met is shown in figure 6. The cases studied here all reported ZR or ZL at the surface, so they do not match the Roselawn situation in that respect where surface temperatures were about $+5^{\circ} \mathrm{C}$ or so and intermittent ordinary rain was occurring.

\section{Where Does Elevated ZL Occur?}

Stratiform Clouds-Geographically, elevated ZL has been documented under certain conditions in stratiform clouds by research aircraft in California, Northern Arizona, Colorado, Texas, and Newfoundland.

Convective Clouds-As was pointed out for elevated ZR, worse icing conditions can occur at higher altitudes in thunderstorms in summer-like conditions. Changnon et al. [15] report that for large, growing convective clouds in Illinois "Typical in-cloud results at $-10^{\circ} \mathrm{C}$ reveal multiple updrafts that tend to be filled with large amounts of supercooled drizzle and raindrops." This means that aircraft penetrating the cores of these clouds in the 0 to $-20^{\circ} \mathrm{C}$ range can expect to encounter intense bursts of ZL too. It is not known how long these encounters can last but because these clouds are usually of limited horizontal extent the ZL is not expected to last as long as may be possible in stratiform clouds. Nevertheless, the windshield may ice over more than usual and prompt the flight crew to report severe icing conditions. 


\section{GENERAL OBSERVATIONS FROM AIRCRAFT MEASUREMENTS.}

Conventional information about ZR and ZL comes from routine weather observations, at airports primarily, where precipitation type is reported and precipitation amounts are indicated by rain gauges. The precipitation amounts are normally averages over an hour or longer, and for ZR and ZL they are usually reported only as light, moderate, or heavy, rather than as numerical amounts in inches (or $\mathrm{mm}$ ) per hour.

Measurements of dropsizes and water concentrations in ZR or ZL are rare, even at ground level. The measurement of these quantities requires special efforts because the basic cloud physics probes Forward Scattering Spectrometer Probe (FSSP) droplet counter and hot-wire RWC indicators do not detect droplets larger than $50 \mu \mathrm{m}$. Even the vibrating rod ice detectors may not indicate correct water concentrations when temperatures are only a few degrees below freezing. Probes designed for large droplets (e.g., Particle Measurement Systems (PMS) 1D-C, 1D-P, 2D$\mathrm{C}$, and 2D-P droplet counters or droplet impactor devices) must be employed to detect and register ZL-sized droplets.

ZR MEASUREMENTS BY THE UNIVERSITY OF NORTH DAKOTA (UND). The UND cloud physics research aircraft, a Cessna "Citation," has been flown into conventional, lowaltitude, freezing rain conditions about a dozen times during winter research projects. Three of those encounters, two near Kansas City, Missouri, and one near Grand Forks, North Dakota, have yielded valuable data on droplet size, water concentration, and icing rate in ZR. The encounters occurred during routine takeoff and landing phases of flight since the ZR was confined to low levels.

Figure 7 shows the computed RWC's and MVD's for one of these cases, and table 4 lists pertinent results for all of the encounters. These were the only ZR dropsize measurements available for this report.

Some interesting observations are the following:

From Kansas City, Missouri, on February 1, 1990

- Although the surface air temperature was -1 or $-2^{\circ} \mathrm{C}$, the temperature decreased to as much as $-8^{\circ} \mathrm{C}$ at the coldest point in the ZR layer, which was from 3000 to $4000 \mathrm{ft}$ deep in these cases.

- Ice accumulation on the ice detector starts within 6 seconds after descending into the top of the subfreezing layer.

- $\quad$ During about 30 minutes of level flight in ZR at 2200-ft AGL (and $-6^{\circ} \mathrm{C}$ ), the Rosemount ice detector registered an accumulation of at least $9 \mathrm{~mm}$ of ice $(0.7$ 
inch/hour). The flight crew had to increase fuel consumption by 60 percent (from 500 to $800 \mathrm{lbs} / \mathrm{hr}$ on each side) to maintain the uniced performance level.

From Kansas City, Missouri, on February 14, 1990

- The aircraft spent about 16 minutes in the ZR layer during approach and landing, during which time the Rosemount ice detector registered about $4 \mathrm{~mm}$ (1/6-inch) of ice accretion.

- A supercooled cloud layer with LWC up to $0.4 \mathrm{~g} / \mathrm{m}^{3}$ often forms in the cold air during ZR conditions. This can add to the ice accretion from the ZR itself.

- The fastest ice accretion appears to occur where the temperature is lowest in the freezing rain layer.

THE CANADIAN ATMOSPHERIC ENVIRONMENT SERVICE PROJECTS. Airborne measurements of elevated ZL are also few, although awareness and interest increased after Wyoming and National Center for Atmospheric Research (NCAR) researchers began finding it in more places. The other agency known to have collected data in elevated ZL is the Canadian Atmospheric Environment Service (AES).

The AES has just completed a field project dedicated to the study of ZR and ZL aloft during March of 1995. The project was based at St. John's Newfoundland and used an instrumented Convair-580 aircraft. Climatologically, freezing precipitation is known to be relatively frequent over the Canadian Atlantic Maritime Provinces. Occasional flights into ZR or ZL had occurred during some of their earlier field projects, such as the Canadian Atlantic Storms Project (CASP-I and especially CASP-II). The results from the 1995 project have not been published yet, but some of the results from CASP-II are available [14].

In CASP-II, four flights encountered ZL in cloud layers of depths of $1 \mathrm{~km}(3000 \mathrm{ft})$ or less. They were based as low as 300-m (1000-ft) ASL and as high as $3.3 \mathrm{~km}(10,000 \mathrm{ft})$. In all four cases, there was no warm layer aloft as in the classical ZR situation. These were entirely subfreezing conditions. Maximum average LWC's (for cloud and drizzle droplet sizes together) were 0.2 to $0.3 \mathrm{~g} / \mathrm{m}^{3}$, and the drizzle dropsizes spanned 100 to $500 \mu \mathrm{m}$ in diameter. The median droplet concentration for droplets larger than $40 \mu \mathrm{m}$ in diameter was only 20 droplets per liter (compared to 60 or more per cubic centimeter for ordinary cloud droplets in maritime air). Two of the encounters, one between 600- and 1200-m (2000- to $4000-\mathrm{ft})$ ASL $\left(-8\right.$ to $\left.-13^{\circ} \mathrm{C}\right)$ and the other between 3- and $3.8-\mathrm{km}(10,000-$ and $12,500-\mathrm{ft})$ ASL $\left(-8\right.$ to $\left.-11^{\circ} \mathrm{C}\right)$, resulted in "moderate to severe" icing. This iced over the windshield and formed $1 \mathrm{~cm}$ of ice on some visible probes and required the aircraft to exit the $\mathrm{ZL}$ conditions after five minutes of exposure. 
FLYING IN FREEZING RAIN. The most familiar and common type of freezing rain is that occurring in the lowest few thousand feet AGL in winter. It normally occurs in warm frontal situations where a layer of warm air aloft, with snow above it, is overriding a layer of subfreezing air in place at the surface.

Freezing rain usually causes conformal, widespread, glaze-like ice. In thin amounts it may be clear, smooth, and difficult to see on the airframe. In larger amounts it may become somewhat knobby and easier to recognize. Although the effects are not well documented, they may range from an iced-over windshield to increasing power and angle of attack requirements to overcome the accumulating weight and drag of the ice.

Low-Lying Freezing Rain. Low-lying freezing rain has a "warm" $\left(\mathrm{T}>0^{\circ} \mathrm{C}\right)$ layer above it and a usually deep snow "cloud" above that. Snow falling into the warm layer melts into the raindrops which continue down into an underlying frigid layer to become freezing rain.

The warm layer is the familiar escape route that is reached by climbing to warm temperatures when you find yourself in a freezing rain zone below. This is contrary to the normal situation where you descend to find warmer air. There is no escape at lower altitudes because the temperatures may get even colder there, and the freezing rain continues all the way to the ground. The ground level temperatures may be only -1 or $-2^{\circ} \mathrm{C}$, but in the middle of the freezing rain layer above, temperatures can reach $-9^{\circ} \mathrm{C}$ or below. Freezing rain layers may be up to $7000 \mathrm{ft}$ deep.

Although temperatures in the warm layer above can sometimes reach a comfortable, icing-free, $+10^{\circ} \mathrm{C}$, they may sometimes be barely warmer than $0^{\circ} \mathrm{C}$. In this case, a cold-soaked airplane may still accumulate slushy ice from partially melted snowflakes impacting the cold airframe. The warm layer may or may not be cloud free.

Elevated Freezing Rain. Elevated freezing rain can occur in summer-like convective clouds that are vigorously growing above the freezing level. Researchers have reported abundant amounts of freezing rain or freezing drizzle in strong updrafts at the $-10^{\circ} \mathrm{C}$ level, for example. Except in unusual circumstances, these clouds would be normally avoided anyway. Depending on the width of the cloud, the freezing rain encountered may be brief but intense. Effects may range from a rapid iceover of the windshield to jet engine power loss.

FLYING IN FREEZING DRIZZLE. Most stratiform clouds do not seem to produce a significant amount of drizzle. But in certain conditions, including upslope clouds, warm front conditions, windy and turbulent cloud layers, and coastal maritime clouds, drizzle production can sometimes be unusually efficient.

Contrary to usual freezing rain conditions where a "warm" $\left(\mathrm{T}>0^{\circ} \mathrm{C}\right)$ layer can be reached by climbing a few thousand feet, freezing drizzle often forms with no warm layer above it. In this case, the escape options are to turn back, climb above the cloud layer, or descend below the freezing level if it is high enough for ground obstacle clearance. Climbing above the drizzle- 
producing cloud layer may be preferable to descending below the freezing level. In flight below the freezing level a cold-soaked airplane may still accumulate ice from drizzle falling on the cold skin of the aircraft. This is especially true when the accessible warm temperatures are only one or two degrees Celsius above zero. On the other hand, climbing increases the angle of attack which increases the rate at which freezing drizzle can accumulate as a thin but rough layer far back on the underside of the wing. Five minutes of exposure is known to produce considerable drag penalties and reduced rate of climb capability on some airplanes. So climbing penetrations of drizzle clouds should be completed quickly.

Low-Lying Drizzle Clouds. Low-lying drizzle clouds can extend from near ground level up to 13,000-ft AGL. This means that after takeoff you may not break out of the drizzle until you pass $13,000 \mathrm{ft}(4 \mathrm{~km})$. If there is cloud and drizzle below 5000-ft AGL, then most likely there will be low ceiling conditions there too. This means that on descent you may be in freezing drizzle some or all the way to touchdown.

There may or may not be a warm $\left(\mathrm{T}>0^{\circ} \mathrm{C}\right)$ layer at some level in the cloud. The upper part of the drizzle cloud may be warm and the lower part cold $\left(\mathrm{T}<0^{\circ} \mathrm{C}\right)$, or vice versa. Or the cloud may be warm in the middle but cold in both the upper and lower parts.

Elevated Freezing Drizzle. Elevated freezing drizzle may occur in separate, nonglaciated (i.e., supercooled liquid droplet) clouds between 5000- and 20,000-ft AGL. These cloud layers are usually less than $8000 \mathrm{ft}$ deep, with a drier, cloud-free interval above and below. The temperature is below $0^{\circ} \mathrm{C}$ throughout the elevated drizzle cloud. The temperature decreases steadily with height, sometimes reaching as low as $-20^{\circ} \mathrm{C}$ at cloud top. Freezing drizzle may extend some distance below the cloud layer until the slowly falling droplets evaporate in the drier air below.

\section{EXISTING DESIGN VALUES.}

CIVIL. There are no officially specified design criteria for ZR and ZL conditions, contrary to the case for ordinary supercooled clouds. This is because there is presently no requirement, by civil aviation authorities, for certifying or testing aircraft for flight into ZR and ZL conditions [16].

Although no official design standards for ZR and ZL exist, some representative values of RWC and dropsizes were proposed in the past. The first of these was contained along with design values proposed by National Advisory Committee for Aeronautics (NACA) in 1949 for supercooled clouds [17]. The proposed values for ZR were

$$
\begin{aligned}
& \text { RWC }=0.15 \mathrm{~g} / \mathrm{m}^{3} \\
& \mathrm{MVD}=1 \mathrm{~mm}(\text { diameter }) \\
& \mathrm{OAT}=-4 \text { to } 0^{\circ} \mathrm{C}\left(+25 \text { to }+32^{\circ} \mathrm{F}\right) \\
& \text { Altitude }=0 \text { to } 1.5 \mathrm{~km}(0 \text { to } 5000 \mathrm{ft}) \\
& \text { Horizontal Extent }=160 \mathrm{~km}(100 \text { miles }) .
\end{aligned}
$$


The RWC value was not obtained from any measurement data but rather by mathematical conversion from the then-estimated maximum rain rates of $2.5 \mathrm{~mm} / \mathrm{hr}(0.1 \mathrm{in} / \mathrm{hr})$ for $\mathrm{ZR}$. The above design values were accepted as suitable by a 1963 technical report to the FAA [18]. This report, which summarizes the then-current knowledge of the icing environment and provides detailed engineering design guidance, has remained a major guidebook among ice protection engineers to this day. No design values for freezing drizzle have been proposed.

MILITARY. For military aircraft, the environmental design philosophy usually requires the capability to withstand certain environmental extremes. For example, U.S. Army regulations of 1969 stipulated that Army "materiel" must be designed to withstand extreme conditions that are present only 1 percent of the time in the most extreme month in the most extreme area of the world [19]. Actual data or information on environmental extremes must be found elsewhere, however. For the U.S. military, approved standards for the most commonly encountered variables are provided in an official reference document [20]. Additional information on environmental extremes may be found in other volumes [21, 22]. While all of these references contain data on rainfall rates, none contain information specifically for ZR or ZL.

In an attempt to develop design values for U.S. Army helicopters, a 1975 report [23] drew on the hourly rain rate statistics of reference 1 to find the extreme ( 99 percent) limit for RWC in ZR conditions. Simple equations borrowed from radar meteorology were used to convert extreme $\mathrm{ZR}$ rain rates to corresponding values of $\mathrm{RWC}$ and effective dropsize. The equations are

and

$$
\begin{aligned}
& \operatorname{RWC}\left(\mathrm{g} / \mathrm{m}^{3}\right)=\mathrm{AxR}^{\mathrm{B}} \\
& \operatorname{MVD}(\mathrm{cm})=\mathrm{CxR}^{\mathrm{F}}
\end{aligned}
$$

where $\mathrm{R}$ is the surface hourly rain rate in $\mathrm{mm} / \mathrm{hr}$, and the parameters $\mathrm{A}=0.09, \mathrm{~B}=0.84, \mathrm{C}=0.09$, and $\mathrm{F}=0.21$ are appropriate for freezing rain and drizzle [24]. From these equations, and the rain rate statistics of reference 1 , the estimated 99 percent extremes at $0^{\circ} \mathrm{C}\left(+32^{\circ} \mathrm{F}\right)$ were

$$
\begin{aligned}
& \mathrm{RWC}=0.33 \mathrm{~g} / \mathrm{m}^{3} \\
& \mathrm{MVD}=1.2 \mathrm{~mm} \text { (diameter) }
\end{aligned}
$$

This 99 percent value of RWC is double that proposed in reference 17 due to a factor of two difference in the estimated maximum rain rates. No altitude limits nor horizontal extents are mentioned in the later Army report, but curves (figure 8) showing a rapid decrease in RWC and dropsize versus temperature were given. These curves are apparently based on an observed decline of maximum ZR rain rate with decreasing surface temperatures at the recording sites. The rapid decline may indicate the conversion of liquid precipitation to sleet or other frozen particles when surface temperatures are low. The implication of a reduced hazard may be misleading, however, if it is not realized that freezing rain or freezing drizzle may still exist aloft where the droplets are not yet frozen. 


\section{AVAILABLE DATA FOR FREEZING RAIN.}

RAIN RATES. While there have been some extensive studies of the geographical distribution of ZR and ZL [2, 3], there is less published information on other factors such as rain rates.

One study with some relevant data is a 1958 report [1]. This study used archived surface weather records to obtain a cumulative frequency distribution of rainfall rates and surface temperatures associated with ZR conditions in New England. This study also chronicles some actual in-flight ZR encounters with an instrumented blimp. RWC values were deduced from an onboard icing rate meter. Some details are given in the following sections.

A recent unpublished study in the United Kingdom [13] developed a novel technique for deducing RWC and dropsizes aloft using archived radiosonde data and surface weather reports. The method starts with an estimated dropsize distribution, RWC, and rain rate at the base of the melting layer whose height is revealed by the radiosonde. The radiosonde humidity data is then used to estimate the evaporational changes in dropsize, RWC, and rain rate during the fall of the droplets from the melting layer to the ground. The starting dropsize distribution is iteratively adjusted until the computed surface rain rate matches that recorded in the archived surface observations. Statistics on the heights and thicknesses of the freezing layers were also obtained from these radiosonde data. Pertinent results will be presented below.

At the present time, almost all estimates of RWC in ZR and ZL are based on hourly rain gauge measurements from which rain rates are estimated for surface observing sites. Therefore the comparison of estimated maximum rain rates for $\mathrm{ZR}$ and $\mathrm{ZL}$ is of interest. The available results are summarized below.

Rain gauge data from New England [1, 27]. See figure 9.

- Maximum indicated rain rate $=7.5 \mathrm{~mm} / \mathrm{hr}(0.3 \mathrm{in} / \mathrm{hr})$,

- 99 percent of all cases less than $5 \mathrm{~mm} / \mathrm{hr}(0.2 \mathrm{in} / \mathrm{hr})$.

(Basis: Two-year period.)

Rain gauge data from the United Kingdom [25].

- Maximum measured rain rate $=4.5 \mathrm{~mm} / \mathrm{hr}(0.2 \mathrm{in} / \mathrm{hr})$,

- Average rate $=1 \mathrm{~mm} / \mathrm{hr}(0.04 \mathrm{in} / \mathrm{hr})$.

(Basis: 30 cases over a two-year period.)

About all that can be said for these results is that the original estimate of $2.5 \mathrm{~mm} / \mathrm{hr}$ [17] is too low for a maximum value. The two sources above are in good agreement with each other if the maximum value of the second source is equated with the 99 percent value of the first.

RAINWATER CONCENTRATION (RWC). The estimates for RWC extreme values are listed below. RWC's computed from rain rates will exhibit the same relationship to each other as do 
the rain rates. This is because, according to equation $1, \mathrm{RWC}$ is nearly directly proportional to the rain rate.

New England rain gauge data [1,27]. (RWC computed from equation 1.)

- 99 percent extreme $\mathrm{RWC}=0.33 \mathrm{~g} / \mathrm{m}^{3}\left(\right.$ at $\left.0^{\circ} \mathrm{C}\right)$.

Icing rate meter data on an instrumented blimp (table 3).

- Indicated RWC's up to $0.5 \mathrm{~g} / \mathrm{m}^{3}$.

Estimates from radiosondes over the United Kingdom [13].

- $\quad$ Maximum estimated RWC aloft $=0.3 \mathrm{~g} / \mathrm{m}^{3}$,

- 98 percent of all cases less than $0.22 \mathrm{~g} / \mathrm{m}^{3}$,

- $\quad$ Average value (for either ZR or ZL) $=0.07 \mathrm{~g} / \mathrm{m}^{3}$.

(Basis: 300 cases over 12 years in the United Kingdom.)

As with the rain rate results, the maximum RWC's suggested by these references are double that of the original estimate [17]. It is notable in table 2 that in six out of ten ZR encounters by the blimp, the indicated RWC's are equal or greater than the $0.3 \mathrm{~g} / \mathrm{m}^{3}$ limit suggested by the rain gauge statistics. As mentioned earlier, reference 23 also claims a strong temperature dependence for extreme RWC's (figure 8), but the curves have not been verified.

Measurements by the UND Research Aircraft [26]. See table 4.

- $\quad$ Maximum observed $\mathrm{RWC}=0.3 \mathrm{~g} / \mathrm{m}^{3}$,

- $\quad$ Typical $\mathrm{RWC}=0.15 \mathrm{~g} / \mathrm{m}^{3}$.

DROPLET SIZES. Previously suggested design values for dropsizes in ZR and ZL appear to be based on known characteristics of ordinary stratiform rain. Logically there should be no appreciable differences between freezing rain and "warm" rain for similar rain rates, except for case-to-case variations in vertical distances over which coalescence and evaporation effects can operate.

Dropsizes for ordinary stratiform rain [32].

- Dropsize range $=0.25$ to $2.5 \mathrm{~mm}$,

(for rain rates up to $5 \mathrm{~mm} / \mathrm{hr}$.)

New England rain gauge data [1, 27]. (MVD computed from equation 2.)

- 99 percent extreme MVD = $1.3 \mathrm{~mm}$. 
Measurements by the UND Research Aircraft [26].

- Largest observed diameter $=3 \mathrm{~mm}$.

- Typical MVD (for D $>0.3 \mathrm{~mm})=0.8 \mathrm{~mm}$.

One reference [23] points out that the precise size of ZR droplets is really of minor importance, because the large droplet sizes involved ensure collection efficiencies near 100 percent anyway.

AIR TEMPERATURE. Among the variables of interest here, air temperature statistics are more plentiful since temperature is easy to measure and data are available from routine observations. The available information is as follows.

Surface temperatures during ZR in New England [1, 27]. See figure 10.

- Of all surface temperatures are above $-9^{\circ} \mathrm{C}$.

- The median value is $-2^{\circ} \mathrm{C}$.

(Basis: A two-year period for New England.)

An important consideration is that, aside from any regional effects, surface temperatures are biased towards warmer values compared to temperatures above ground in the freezing layer. That is, surface air temperatures will not reveal the fact that temperature profiles like that for San Antonio in figure 4 extend to much lower temperatures aloft and that the freezing rain may reach to higher altitudes as well. Therefore, ZR temperature statistics for aviation purposes must be based on temperatures aloft and not on the usual surface data alone.

Radiosonde data during ZR over the United Kingdom [13]

- Of the temperatures in the freezing rain layer are above $-4^{\circ} \mathrm{C}$.

- The median value is $-1^{\circ} \mathrm{C}$.

(Basis: 300 radiosonde launches.)

Radiosonde data during ZR over the U.S.A. (reference this study). See table 5.

- Lowest temperature in a freezing rain layer $=-11^{\circ} \mathrm{C}$.

- Typical range: -4 to $-9^{\circ} \mathrm{C}$.

(Basis: 130 radiosonde launches in $\mathrm{ZR}$ and $\mathrm{ZL}$.)

There are regional differences in the range and average values of air temperature associated with ZR and ZL conditions. Data from the U.K. show $-5^{\circ} \mathrm{C}$ as about the lowest temperatures to be expected, while in New England (U.S.A.), temperatures down to $-12^{\circ} \mathrm{C}$ have been recorded during ZR. 
Measurements by the UND Research Aircraft [26]. See table 4.

- Lowest temperature in a freezing rain layer $=-8^{\circ} \mathrm{C}$.

- Typical range: 0 to $-4^{\circ} \mathrm{C}$.

(Basis: eight passes through three different freezing rain episodes.)

DEPTH OF FREEZING RAIN LAYERS. Radiosonde data over the United Kingdom and parts of Europe [13] provided information on freezing layers (below elevated, warm inversions) that were found to be up to $6000 \mathrm{ft}(2 \mathrm{~km})$ deep over the United Kingdom, but 92 percent of the layers were shallower than $2000 \mathrm{ft}(0.6 \mathrm{~km})$. There appeared to be some regional differences in the average depth of the freezing layers, however. Preliminary results from radiosonde data over France and Norway show possibly 15 to 30 percent, respectively, of the freezing layer depths are deeper than $2000 \mathrm{ft}(0.6 \mathrm{~km})$. Average depths over France and Norway are about $1200 \mathrm{ft}(0.35$ $\mathrm{km})$ and $1450 \mathrm{ft}(0.45 \mathrm{~km})$, respectively, compared to about $850 \mathrm{ft}(0.25 \mathrm{~km})$ over the U.K. In any case, the available data show that there are geographical differences in expected temperatures and heights and depths of the freezing layers.

Radiosonde data over the U.S.A. (reference this study).

- Maximum depth $=6900 \mathrm{ft}$.

HORIZONTAL EXTENT OR EXPOSURE TIME. No quantitative information is known to be available for horizontal extents of ZR and ZL conditions. The climatological and geographical study of reference 2 points out that ZR is usually associated with warm fronts or other situations involving warm air overrunning cold air. Therefore, ZR conditions can extend several hundred miles along the front and much less in a direction perpendicular to the front. The design values proposed in [17] used 100 miles as a representative value.

Realistically, a prolonged exposure is most likely to occur during approach and landing because the phenomenon is usually confined to the lowest several thousand feet AGL. Therefore, it may be more practical to postulate an exposure that is representative of the time that could be spent below 7000-ft AGL during hypothetical, but realistic, approach and landing situations in freezing rain. The exposure would depend on several considerations, such as the individual aircraft type, approach patterns, and airport conditions. The latter would include any landing delays and air traffic control procedures during freezing rain. The time during takeoff and accent to $7000-\mathrm{ft}$ AGL may be a critical exposure too.

\section{AVAILABLE DATA FOR FREEZING DRIZZLE.}

An authoritative handbook [29] published by the American Meteorological Society describes drizzle as follows. Drizzle (sometimes popularly called mist) consists of very small, numerous, and uniformly dispersed water drops that may appear to float while following air currents. Unlike fog droplets, drizzle falls to the ground. It usually falls from low stratus clouds and is frequently accompanied by low visibility and fog. 
DROPLET SIZES. By convention, drizzle drops are taken to be less than $0.5 \mathrm{~mm}$ in diameter. Larger drops are considered raindrops. The largest size for drizzle is limited by the mechanism by which drizzle is formed. Contrary to freezing rain, where the largest dropsize depends on the size of the melting snowflakes which turn into rain, drizzle drops have to grow by the gradual collection of mostly smaller cloud droplets as the drizzle drops descend through the cloud(s). The maximum dropsize is therefore limited in part by the depth of the cloud. Observation shows that drizzle drops are usually no larger than about $0.5 \mathrm{~mm}(500 \mu \mathrm{m})$ and that the number of droplets at any given size decreases more or less exponentially as the size increases toward $0.5 \mathrm{~mm}$. That is, by far the greatest number of drizzle droplets are in the smaller sizes.

Because the droplet concentration changes so rapidly with droplet size, it is usually desirable to divide the overall size range into many narrow subintervals in order to accurately display the variation. Modern, electro-optical, droplet sizing probes do this by automatically tallying the number of droplets detected in each of 15 or more narrow-size intervals. A typical graphical presentation of the results often looks like that shown in figure 11. Because of the wide range in both dropsize and droplet numbers over the size range, logarithmic scales are often used to compress the scales to fit a single page and to preserve the detail in both the small dropsizes and the low droplet concentrations. In addition, in order to make the results universally comparable (independent of the probe), it is necessary to plot the number of droplets per unit volume of air per unit size interval instead of simply the number of droplets detected in each size interval. While these conventions are often necessary for accurate scientific depiction and unambiguous use of the data, they obviously add considerable complication to the matter. For one thing, it is difficult to quickly assess the significance of the differences between two or more sets of results. For example, what is the significance of the difference between the curves beyond $100 \mu \mathrm{m}$ in figure 11 ?

In order to avoid these complications and to simplify the interpretation of dropsize and water concentration data, the MVD has been traditionally used as a single variable substitute to represent conventional cloud droplet distributions for aircraft icing purposes. The MVD conveniently indicates the dropsize which divides the water concentration in half. That is, by definition, half of the available water in the droplet population is contained in droplets smaller than the MVD and half is contained in larger droplets. But the MVD is known to be unsatisfactory when wide dropsize ranges are involved.

When drizzle-sized droplets are present in clouds, they stretch the droplet size distribution to larger sizes but do not always add a sizable fraction to the LWC or MVD. For example, table 6 shows several actual cases where droplets were detected out to $200 \mu \mathrm{m}$ or more, but they increased the overall LWC and MVD by less than 70 percent and 33 percent, respectively. In this case, the MVD is still dominated by the ordinary cloud droplet contribution to the total LWC, and the resultant MVD, taking into account the cloud and drizzle droplets together, is still less than $40 \mu \mathrm{m}$. That remains within the range of FARs 25 and 29, Appendix C. As a result, the MVD gives no clue that drizzle droplets are present. And bulk catch efficiencies, computed with the MVD alone, may underestimate the total ice accretion. To overcome this inadequacy in 
dropsize representation, several alternate methods have been suggested in order to better represent the large droplet "tail" of the size distribution.

\section{Alternates to the MVD.}

The Maximum Diameter. This variable is designed to indicate the dropsize below which 95 percent of the LWC lies. This would not only be quite sensitive to the presence of large droplets, but it would usefully indicate to icing practitioners the droplet range where the LWC is confined.

The 80 Percent Volume Diameter (VD). This variable is also a good indicator of large droplets, and it is argued, it would not fluctuate as much as the 95 percent VD when computing it from measured dropsize samples. This is because the 80 percent VD should be less sensitive to the infrequent and statistically uncertain counts for the largest droplets that show up only intermittently in particle counter samples.

Drizzle-Specific LWC and MVD. Present thinking, supported by some tanker spray results, is that icing due to freezing precipitation is sufficiently different from that due to ordinary supercooled clouds that the two can be treated separately and independently. This is automatically true if no clouds are present during the ZR or ZL exposure. Therefore, another way to handle the wide range of dropsizes is to compute a LWC and MVD for the ZL or ZR droplets alone. This would separate the ZR or ZL drops from the ordinary cloud droplets for large droplet applications. The drizzle drop or raindrop MVD and LWC would then represent only these larger droplets of interest. It is proposed here that the drizzle-specific water concentration be called DWC to distinguish it from the usual LWC for ordinary cloud droplets.

One question which arises with the latter suggestion is where do you draw the line between ordinary cloud droplets and drizzle droplets? A standard reference [29] admits that size distinctions are somewhat arbitrary but that the size range for ordinary cloud droplets may be considered to extend out to $200 \mu \mathrm{m}(0.2 \mathrm{~mm})$, while drizzle droplets are defined to be less than $500 \mu \mathrm{m}(0.5 \mathrm{~mm})$ in diameter. Larger droplets are termed raindrops. ${ }^{3}$

But a practical consideration is that the standard cloud droplet size spectrometer employed nowadays, the FSSP probe, normally has an upper-size detection limit of about $45 \mu \mathrm{m}$. (Coincidentally, this is nearly identical with the $50 \mu \mathrm{m}$ MVD limit to the conventional icing envelopes in Appendix C of FARs 25 and 29 [28]). Therefore, it has been suggested that for ease of computation and standardization of measurement procedures, the DWC and MVD for drizzle drops be computed from droplet counters that cover droplet diameters larger than $50 \mu \mathrm{m}{ }^{4}$ Two ways of doing this come to mind.

\footnotetext{
${ }^{3}$ Both rain and drizzle involve continuous dropsize spectra that may extend down to ordinary cloud droplet sizes, depending on the circumstances. The main difference in the size distributions is that they can extend to considerably larger dropsizes for ZR.

${ }^{4}$ This, in effect, defines drizzle droplets to be anything larger than $50 \mu \mathrm{m}$ in diameter for present purposes.
} 
The Standard Probe Scheme. This has been proposed by others as a result of trying to characterize the large droplet sprays generated by the USAF airborne spray tanker for the ATR-72 tests in December of 1994. It would standardize on the basic 1D-C or 2D-C probes which can cover the range $50-180 \mu \mathrm{m}$ or $50-600 \mu \mathrm{m}$, respectively, at least. Precipitation probes to detect droplets as large as $6 \mathrm{~mm}$ or more are available, but the $\mathrm{C}$ probes cover the size range of interest with the best resolution. DWC's and MVD's computed from these probes should probably be labeled $\mathrm{DWC}_{>50 \mu \mathrm{m}}$. Or better yet, $\mathrm{DWC}_{50-300 \mu \mathrm{m}}$ or $\mathrm{MVD}_{50-600 \mu \mathrm{m}}$ would unambiguously indicate the droplet size range that was used. In any case, these drizzle-specific DWC variables would usefully indicate how much LWC lies in droplets larger than $50 \mu \mathrm{m}$ in diameter (and possibly outside the current FARs 25 and 29, Appendix C envelopes in the case of ZL or ZR).

The Standard Dropsize-Interval Scheme. This method, introduced here, has some attractive features. Basically, the idea is to establish the convention of reporting all drizzle and freezing rain encounters in terms of DWC or RWC amounts in a few, fixed, dropsize intervals. This is illustrated in table 7. Five dropsize intervals will span the ZL or ZR droplet size range with sufficient resolution for aircraft icing purposes. Reported ZL or ZR encounters can then be easily compared as shown in the table. In addition, once a minimum test spray requirement has been decided upon, it can be expressed in the same manner. Test crews then need only document the DWC or RWC amounts they achieved in each of the fixed size intervals. A glance will quickly tell whether the amounts meet, exceed, or fall below the specified (required) amounts.

This method is convenient for wet wind tunnel operators or spray rig operators. Rather than trying to match some desired dropsize distribution curve plotted on a log-log scale, as is usually the case, they can simply try to adjust their spray nozzles to produce the desired amount of DWC or RWC in each of the several size intervals. A few, fixed dropsizes are more suitable for computer modeling too.

The method is also convenient for routine dropsize measurements, because it allows the use of any dropsize probe(s) that cover the necessary dropsize range. Other variables, such as the MVD, 80 percent VD, or 95 percent VD can still be included as supplementary indicators. The 95 percent VD, for example, would be useful for indicating the practical upper limit to dropsizes for individual cases. But the proposed scheme establishes the five standard dropsize intervals as the primary means for reporting data and specifying test and design requirements.

RAIN RATE. Continuing from reference 29: In weather observations, drizzle is classified as (a) very light, comprised of scattered drops that do not completely wet an exposed surface, regardless of duration; (b) light, the rate of fall being from a trace to 0.001 inch per hour; (c) moderate, the rate of fall being from 0.01 to 0.02 inch per hour; and (d) heavy, the rate of fall being more than 0.02 inch per hour. When precipitation equals or exceeds 0.04 inch per hour, all or part of the precipitation is usually rain; however, true drizzle falling as heavily as 0.05 inch per hour has been observed. 
DRIZZLE WATER CONCENTRATION (DWC). Using the value of 0.05 inch/hour (1.27 $\mathrm{mm} / \mathrm{hr}$ ) stated above as a maximum probable rain rate for drizzle, one can compute from equation 1 a corresponding maximum probable DWC of $0.11 \mathrm{~g} / \mathrm{m}^{3}$. This value may be valid for ground-level conditions, but some airborne measurements have documented DWC's up to 0.2 $\mathrm{g} / \mathrm{m}^{3}$ at least [5].

HORIZONTAL EXTENT OR EXPOSURE TIME. There are no statistics on this, but for lowlying freezing drizzle the situation should be the same as for freezing rain. In this case it may be practical to postulate an exposure that is representative of the time that could be spent below 7000-ft AGL during hypothetical, but realistic, approach and landing situations in freezing drizzle. The exposure would depend on several variables, such as the individual aircraft type, approach patterns, and airport conditions. The latter would include any landing delays and air traffic control procedures during freezing drizzle.

The Roselawn accident has shown us that elevated ZL can at least extend over a typical racetrack holding pattern. In this case it may be practical to postulate a minimum holding time as the exposure requirement.

DEVELOPING NEW DESIGN CRITERIA AND TEST CONDITIONS FOR FREEZING RAIN AND FREEZING DRIZZLE.

Very limited amounts of data are presently available for variables associated with ZR and ZL conditions aloft. This means that any proposed design criteria can only be tentative for the time being. It also means that attention should be focused first on developing necessary information for the most important variables. The approach followed here has been to prioritize the variables according to their importance to the design engineer. In this regard, three categories of design criteria have been conceived. The most important variables and the most important aspects of them are termed "first level" design criteria. Such variables would include RWC, air temperature, and dropsize, at least. The most important aspects of them would be their extreme values, and probably a representative or average value. At the moment, extreme values can only be estimated, but representative values are easily obtainable from the available data. An example of a possible presentation is shown in table 8, along with tentative design values obtained from data presented earlier in this report.

The next category, termed "second level" design criteria, contains any additional variables of secondary importance for design considerations. These include supplemental information that is helpful but not critically necessary. These may include horizontal and vertical extents, time duration of ZR or ZL conditions, and rain rate, for example. Second level information is also considered to contain elaborations on the first level variables. These elaborations may include mean values and frequencies of occurrence or probabilities of exceeding incremental variable values.

"Third level" design criteria are conceived to be those data, analyses, or supplemental information that are informative but mostly of scientific interest. They may be helpful in selecting realistic variable values for specific altitudes or flight scenarios, for example. They 
may also be useful for planning flight tests in natural icing conditions by indicating frequencies of occurrence of RWC values as a function of altitude and temperature, for example. They may also be useful for weather analyses and forecasting purposes. Generally, third level design criteria are a more thorough scientific description of ZR and ZL conditions than is absolutely necessary for purely design considerations. Information on the second and third level criteria have yet to be developed.

\section{SUMMARY AND CONCLUSIONS}

The available radiosonde observations appear to be suitable for obtaining adequate statistical data on temperatures, vertical extents, and probable cloud layers in freezing rain and freezing drizzle conditions aloft. Surface observations of rain rates in freezing rain and freezing drizzle are helpful in estimating the upper limit to the resulting rainwater concentrations near the surface, but some airborne measurements indicate that values aloft can be a little larger.

Actual measurements of dropsizes, water contents, and icing rates are still inadequate for more than initial estimates of average and extreme values of these variables. More data of this kind need to be assembled and analyzed. Several research organizations have recently obtained new data, and the FAA should request a copy of the measurements for use in developing better statistics on the variables of interest. This could greatly improve the confidence in any proposed characterization or design or test conditions for freezing rain and freezing drizzle.

Various terms and acronyms have turned up recently for describing these icing conditions that lie outside of FARs 25 and 29, Appendix C. It is recommended here that the conventional terms freezing rain and freezing drizzle be used exclusively to avoid unnecessary elaboration and confusion.

A new method for reporting and specifying water concentrations and dropsizes is introduced here for freezing rain and drizzle applications. This is needed to overcome the problems and inadequacies of trying to use FARs 25 and 29, Appendix C variables to characterize wide dropsize populations. 


\section{REFERENCES}

1. Lewis, W., and Perkins, P.J., 1958: "A Flight Evaluation and Analysis of the Effect of Icing Conditions on the ZPG-2 Airship," Technical Note No. 4220, National Advisory Committee for Aeronautics, Lewis Flight Propulsion Laboratory, Cleveland, Ohio.

2. Bennett, I., 1959: "Glaze, It's Meteorology and Climatology, Geographical Distribution, and Economic Effects," Technical Report EP-105, U.S. Army Quartermaster Research \& Engineering Center, Natick, Massachusetts.

3. Vilcans, J., 1989: "Climatological Study to Determine the Impact of Icing on the Low Level Wind shear Alert System," Technical Report DOT-TSC-FAA-89-3 (2 Vols.), U.S. Department of Transportation, Transportation Systems Center, Cambridge, Massachusetts 02142.

4. Mason, B.J., and Howorth, B.P., 1952: "Some Characteristics of Stratiform Clouds over North Ireland in Relation to Their Precipitation," Quart. J. Roy. Met. Soc., 78, pp. 226-230.

5. Politovich, M.K., 1989: “Aircraft Icing Caused by Large Supercooled Droplets,” J. Appl. Meteorology, 28, pp. 856-868.

6. Almeida, F.C., 1979: "The Effects of Small-Scale Turbulent Motions on the Growth of a Cloud Droplet Spectrum," J. Atmos. Sci., 36, 1557-1563.

7. Khain, A.P., and Pinsky, M.B., 1995: "Drop Inertia and its Contribution to Turbulent Coalescence in Convective Clouds," J. Atmos. Sci., 52, pp. 196-206.

8. Pobanz, B.M., Marwitz, J.D., and Politovich, M.K., 1994: "Conditions Associated with Large-Drop Regions," J. Appl. Meteor., 33, pp. 1366-1372.

9. Lewis, W., 1947: “A Flight Investigation of the Meteorological Conditions Conducive to the Formation of Ice on Airplanes," Technical Note 1393, National Advisory Committee for Aeronautics, Ames Aeronautical Laboratory, Moffett Field, California.

10. Jeck, R.K., 1980: "Icing Characteristics of Low Altitude, Supercooled Layer Clouds," Report No. FAA-RD-80-24, Federal Aviation Administration, Washington, DC 20591.

11. Sand, W.R., Cooper, W.A., Politovich, M.K., and Veal, D.L., 1984: "Icing Conditions Encountered by a Research Aircraft," J. Climate Appl. Meteor., 23, pp. 1427-1440.

12. Cooper, W.A., Sand, W.R., Politovich, M.K., and Veal, D.L., 1984: "Effects of Icing on Performance of a Research Airplane," J. Aircraft, 21, pp. 708-715. 
13. Mills-Hicks, C.J. and Mansfield, D.A., 1990: "The Climatology of Freezing Rain in the British Isles based on Radiosonde Station Records," Met. O. (P) Special Investigations Technical Memorandum No. 1 (199), Meteorological Office, London Road, Bracknell, Berkshire, RG12 2SZ.

14. Cober, S.G., Isaac, G.A. and Strapp, J.W., 1995: "Aircraft Icing Measurements in East Coast Winter Storms," J. Appl. Meteor., 34, pp. 88-100.

15. Changnon, S.A., Czys, R.R., Scott, R.W., and Westcott, N.E., 1991: "Illinois Precipitation Research: A Focus on Cloud and Precipitation Modification," Bull. Amer. Meteor. Soc., 72, 587 and following.

16. Advisory Circular AC-29-2A (1987): "Certification of Transport Category Rotorcraft," Federal Aviation Administration, Washington, DC 20591.

17. Jones, A.R. and Lewis, W., 1949: "Recommended Values of Meteorological Factors to be Considered in the Design of Aircraft Ice-Prevention Equipment," Technical Note No. 1855, National Advisory Committee for Aeronautics, Ames Aeronautical Laboratory, Moffett Field, California.

18. Bowden, D.T., et al., 1963: "Engineering Summary of Airframe Icing Technical Data," Technical Report ADS-4, Federal Aviation Administration, Washington, DC 20591.

19. Army Regulation AR-70-38 (1969): "Army Aviation-General Provisions."

20. Military Standard-210C (1987): "Climatic Information to Determine Design and Test Requirements for Military Systems and Equipment," U.S. Government Printing Office, Washington, DC.

21. Handbook of Geophysics and the Space Environment, USAF/AFGL.

22. Ludlam, F.H., 1980: "Clouds and Storms," American Meteorological Society, Boston, Massachusetts.

23. Werner, J.B., 1975: "The Development of an Advanced Anti-Icing/Deicing Capability for U.S. Army Helicopters," Vol. 1 - Design Criteria and Technology Considerations. Report No. USAAMRDL-TR-75-34A, U.S. Army Air Mobility Research and Development Laboratory, Ft. Eustis, Virginia 23604.

24. Marshall, J.S. and Palmer, W., 1948: "The Distribution of Raindrops with Size," J. Meteorology, $\underline{5}$, pp. 165-66.

25. Latham, J., University of Manchester Institute of Science and Technology, private communication of data. 
26. University of North Dakota, Dept. of Aerospace Sciences, private communication of data.

27. "Hourly Precipitation Data (New England)," Vols. 5-7 (1955-1957), U.S. Department of Commerce, U.S. Weather Bureau.

28. Federal Aviation Regulation Part 25 (FAR 25), Airworthiness Standards: Transport Category Airplanes, Appendix C; and FAR 29, Airworthiness Standards: Transport Category Rotorcraft, Appendix C; Federal Aviation Administration, Washington, DC 20591.

29. Glossary of Meteorology, 1959, American Meteorological Society, Boston, Massachusetts 02108.

30. Ashendon, R., University of Wyoming, private communication.

31. University of Wyoming, Atmospheric Sciences Dept., private communication of data.

32. Mason, B.J., 1971: “The Physics of Clouds," Clarendon Press, Oxford England.

33. Byers, H.R., 1944: “General Meteorology,” McGraw-Hill Book Co., New York. 


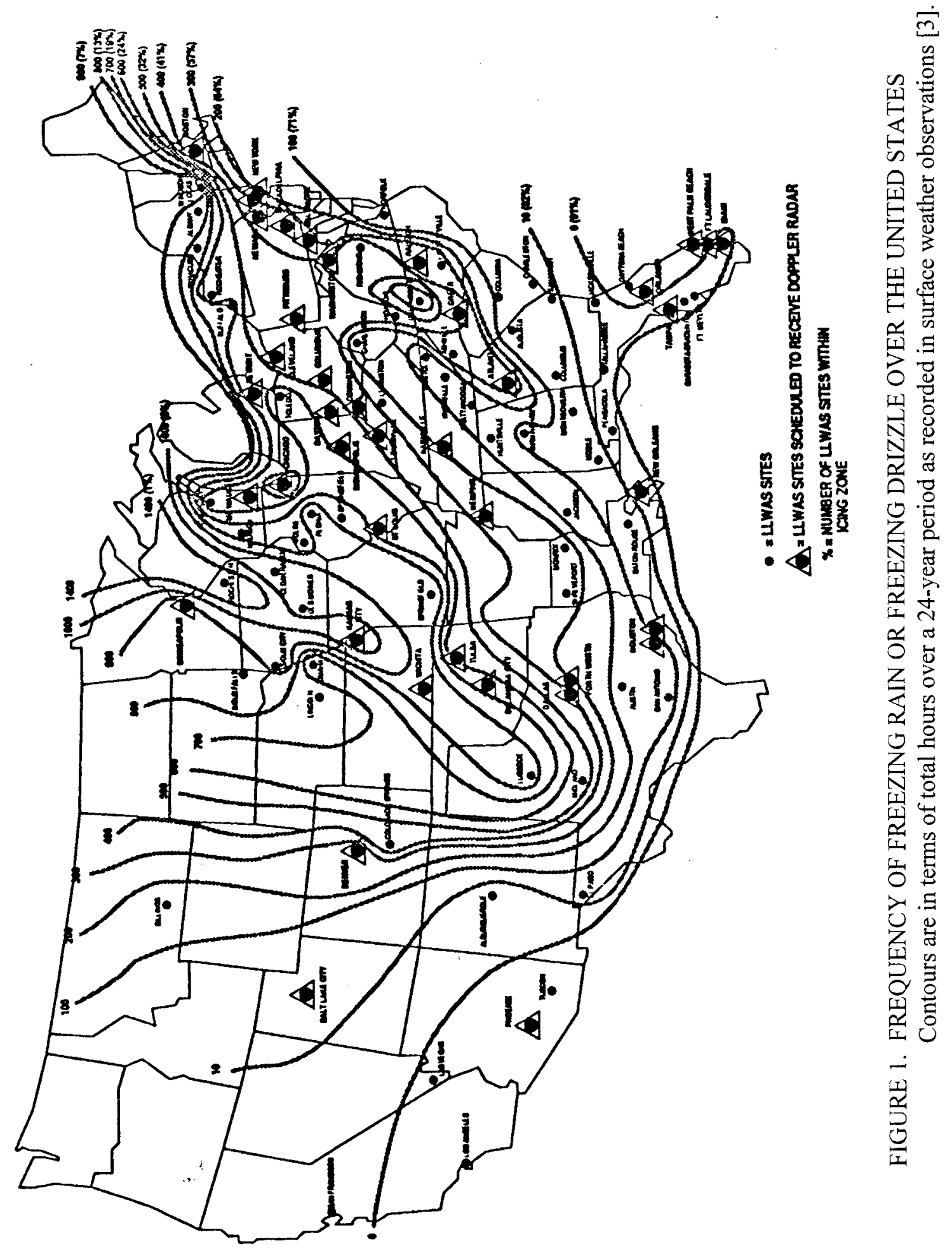




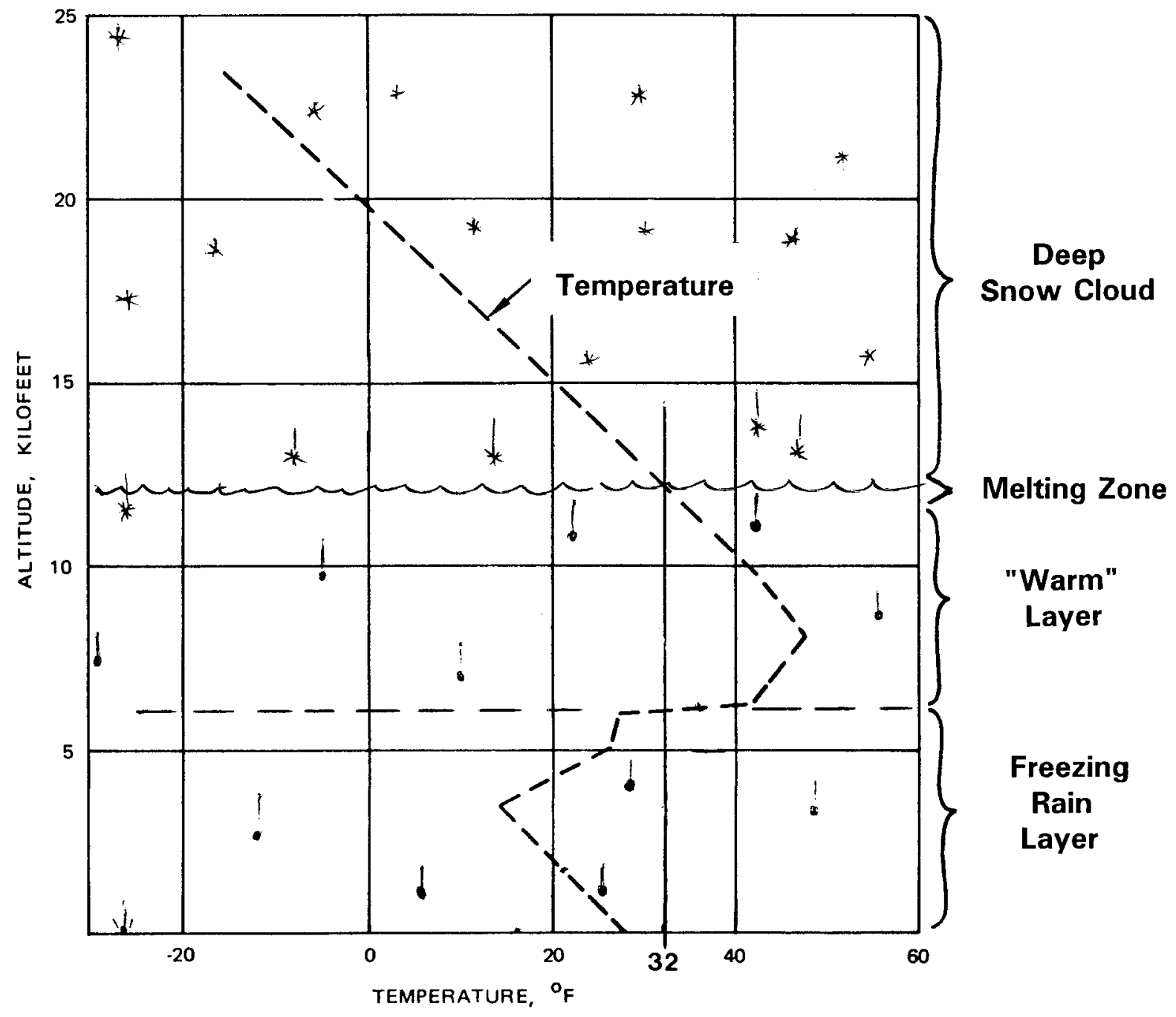

FIGURE 2. SCHEMATIC REPRESENTATION OF FREEZING RAIN CONDITIONS 


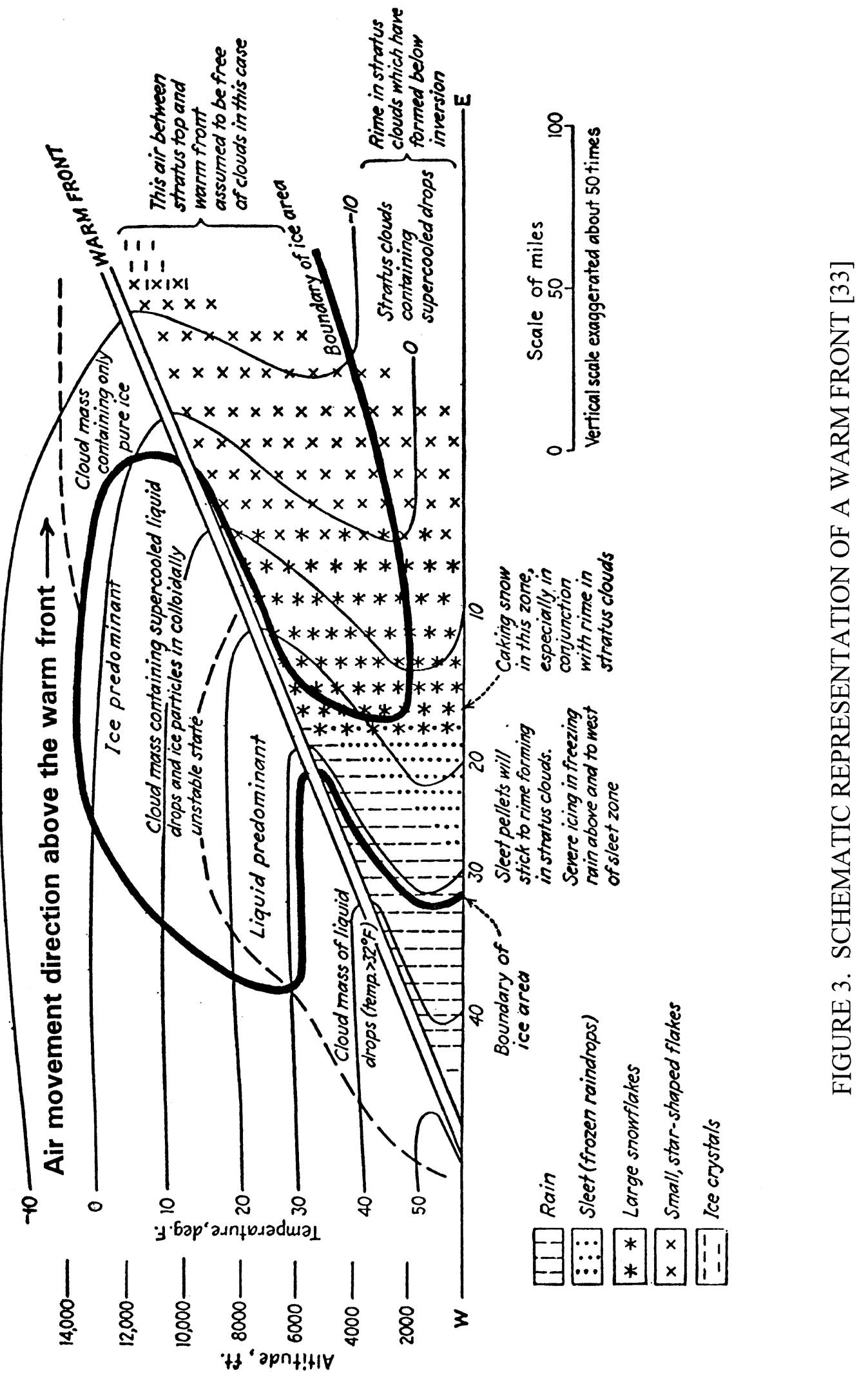




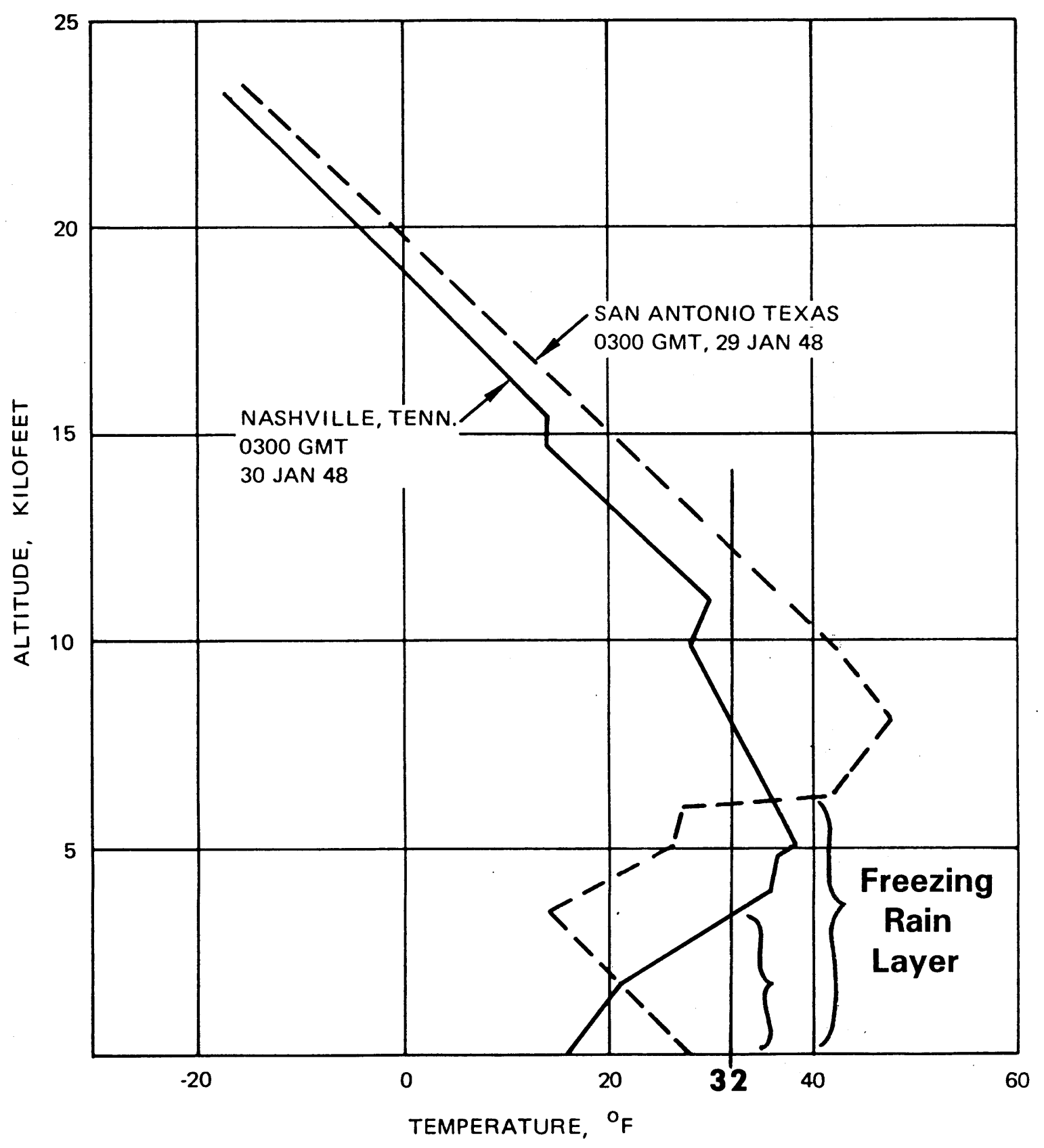

FIGURE 4. SAMPLE TEMPERATURE PROFILES FOR FREEZING RAIN 


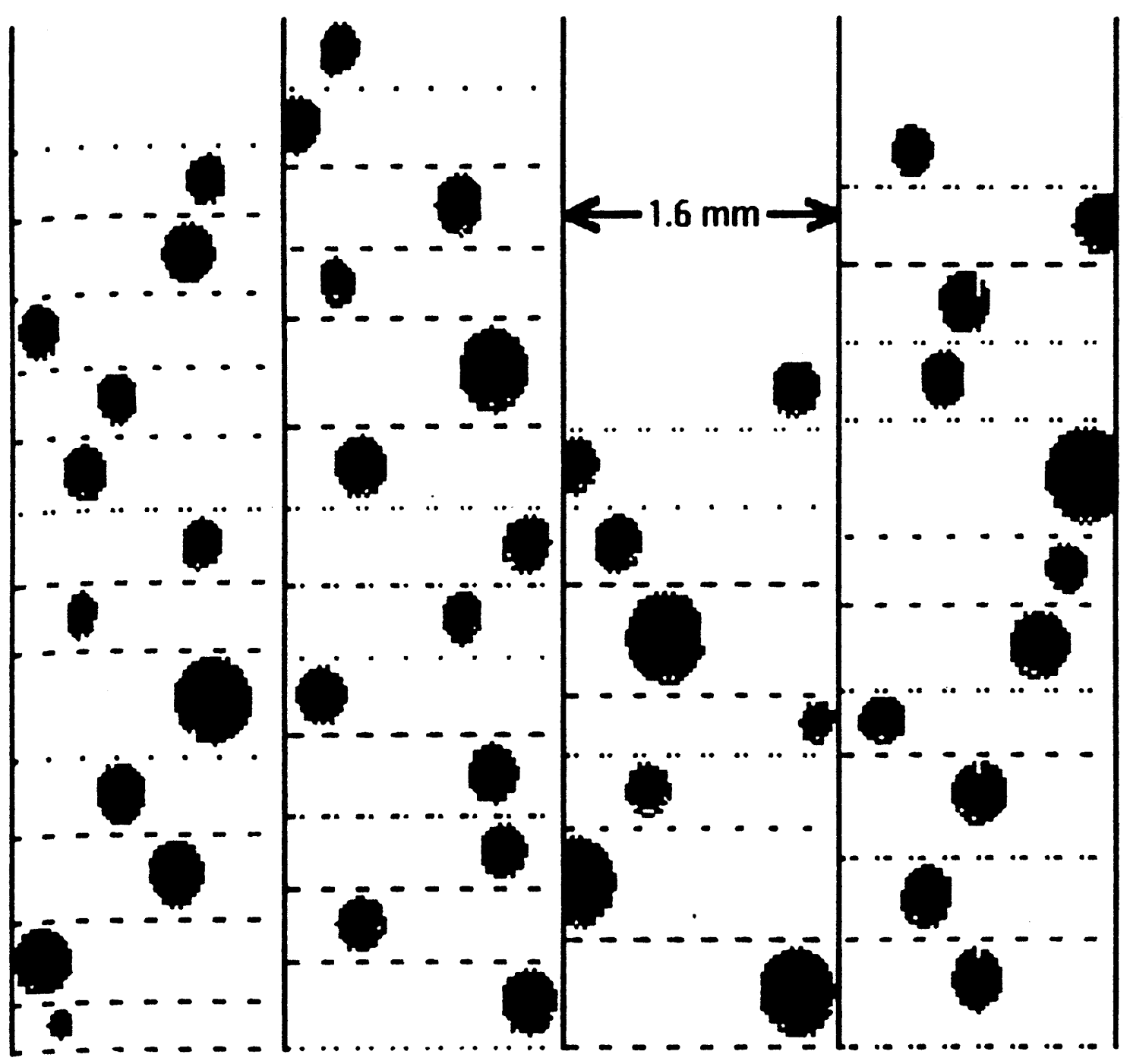

FIGURE 5. MAGNIFIED IMAGES OF FREEZING DRIZZLE DROPLETS. Drizzle was encountered at 10,000 to $12,500 \mathrm{ft}$ and at -8 to $-11^{\circ} \mathrm{C}$. Largest droplets are about $0.4 \mathrm{~mm}$ diameter [14]. 


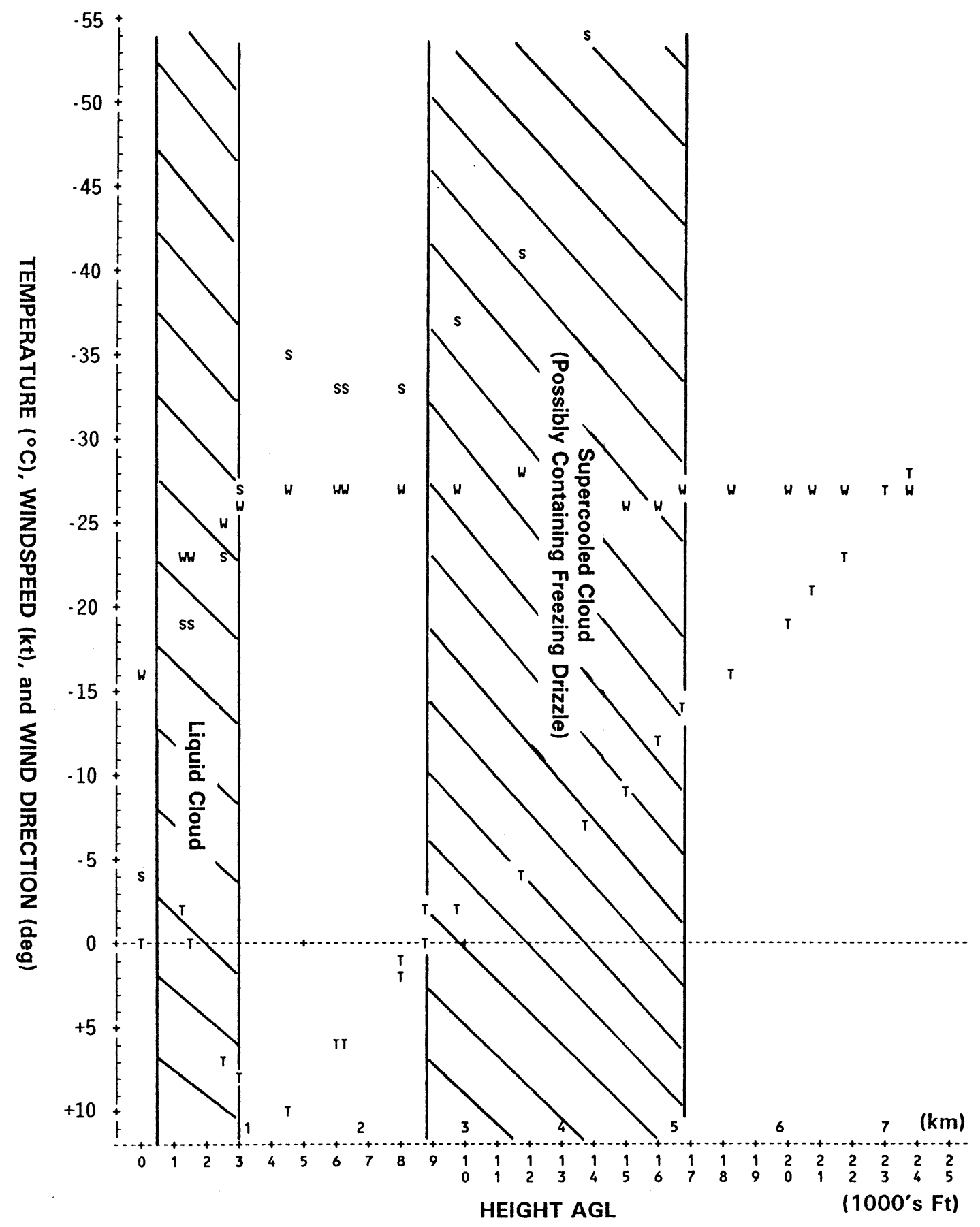

FIGURE 6. EXAMPLE OF MIDLEVEL CLOUD LAYER THAT MAY CONTAIN FREEZING DRIZZLE. Freezing drizzle and freezing rain were reported at the surface. Windshear and turbulence may be creating "large drops" (i.e., freezing drizzle) in the upper cloud layer at temperatures down to $-15^{\circ} \mathrm{C}$. (Cloud layers were inferred from radiosonde humidity data (not shown). Case is for Washington, DC (IAD), January 14, 1971.) 


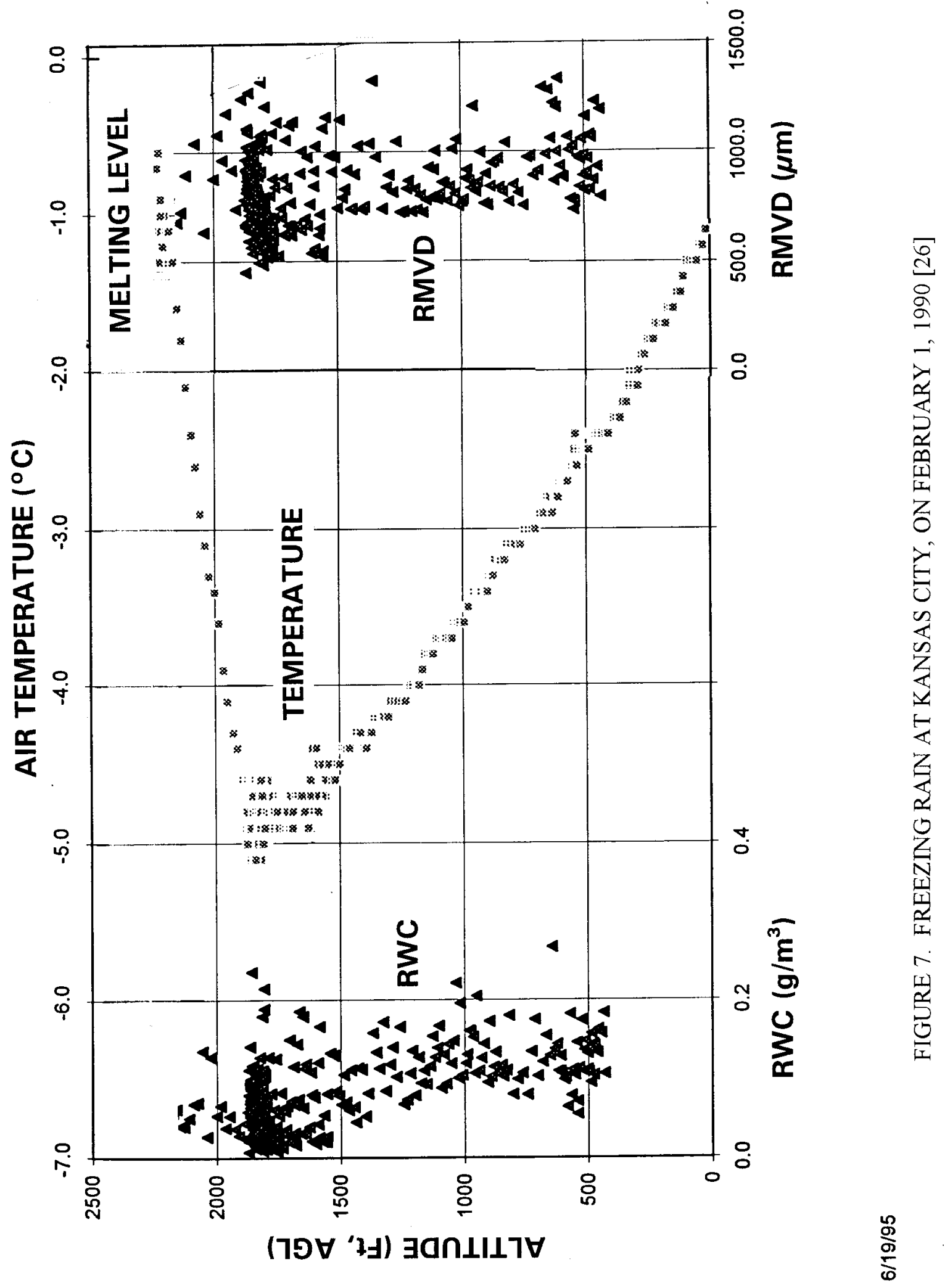



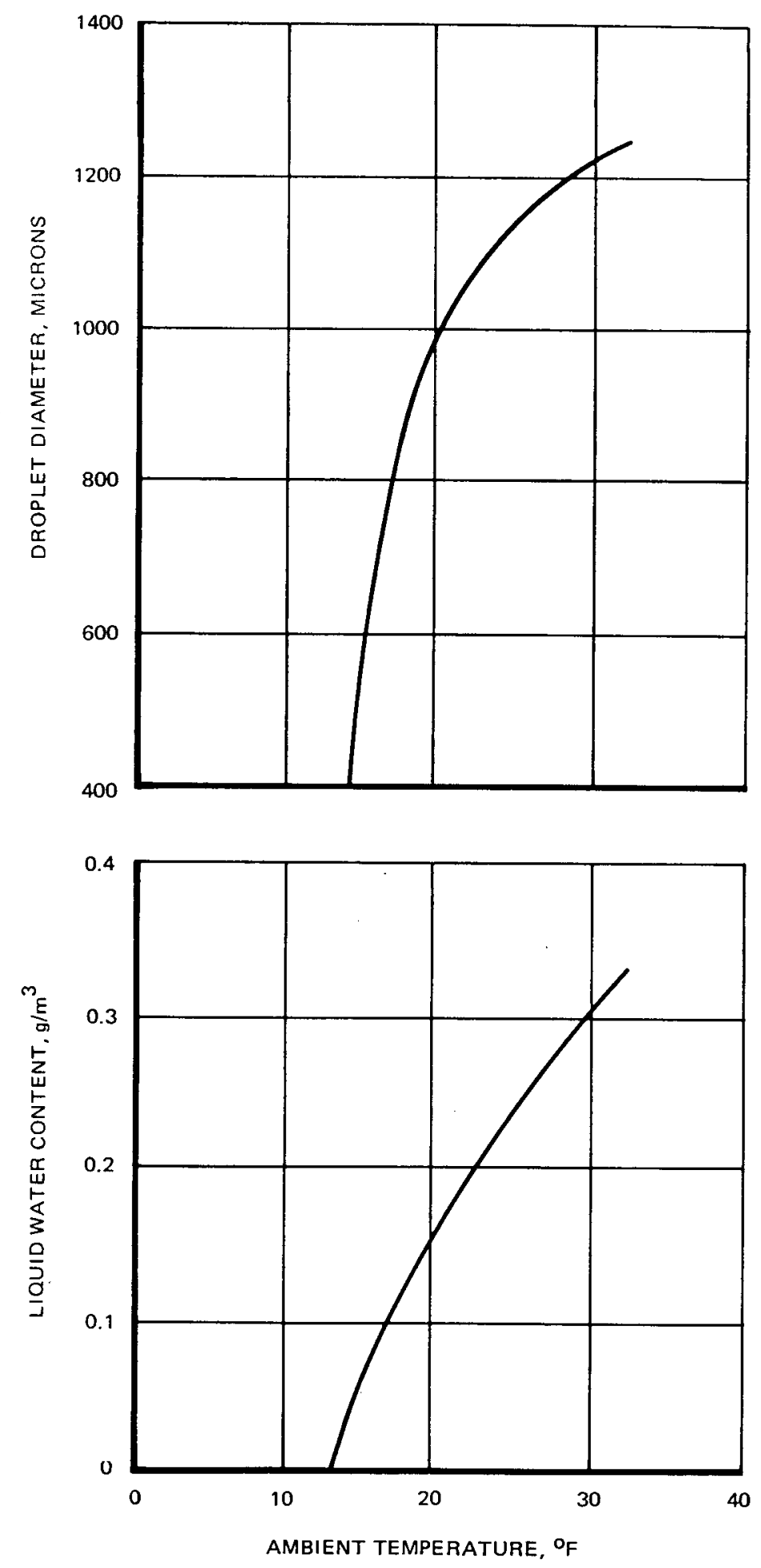

FIGURE 8. PURPORTED 99 PERCENT LIMITS TO RWC AND "DROPLET DIAMETER" AS A FUNCTION OF SURFACE TEMPERATURE IN FREEZING RAIN [23] 


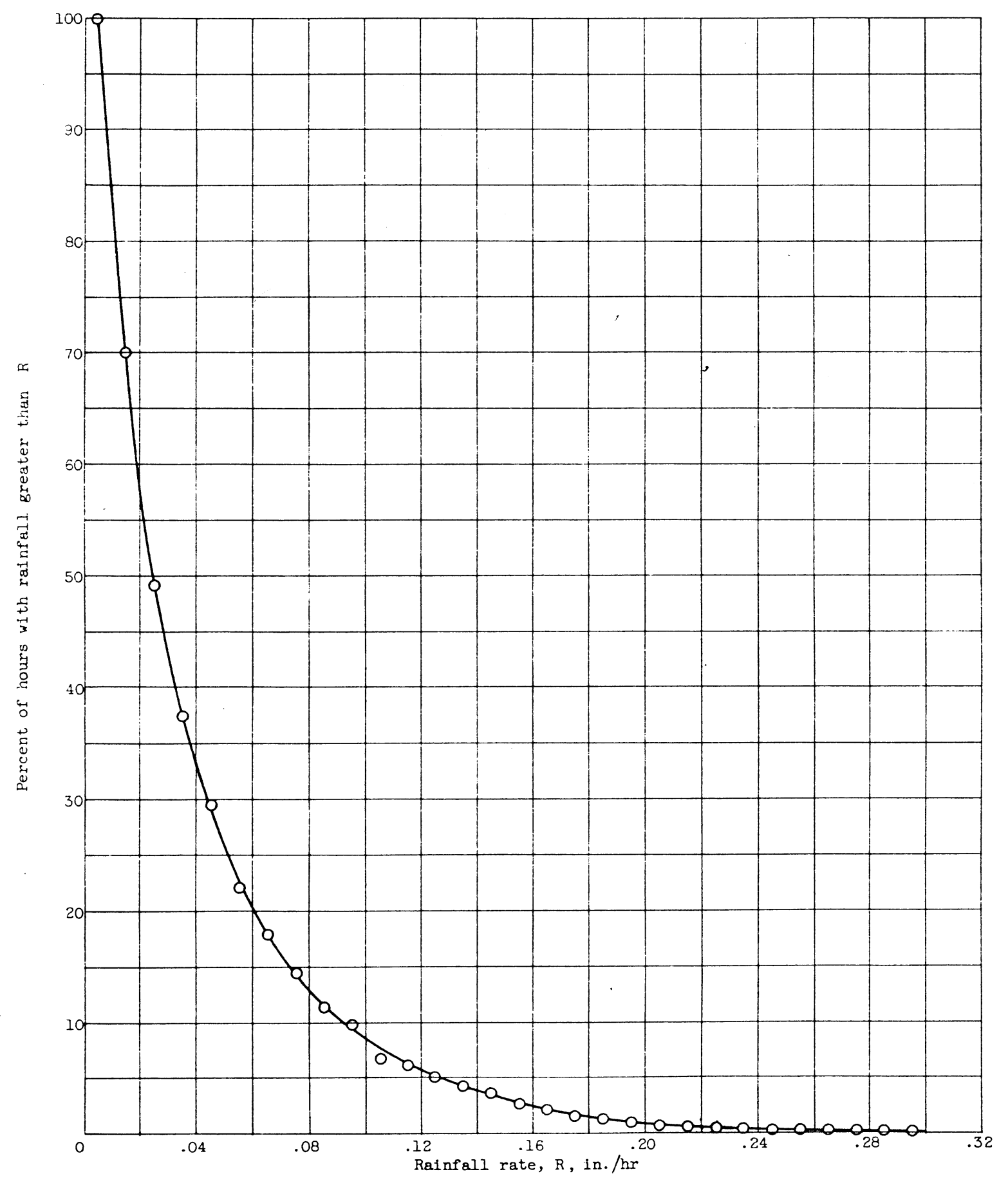

FIGURE 9. FREQUENCY DISTRIBUTION OF COLD RAIN RATES IN NEW ENGLAND [1] 


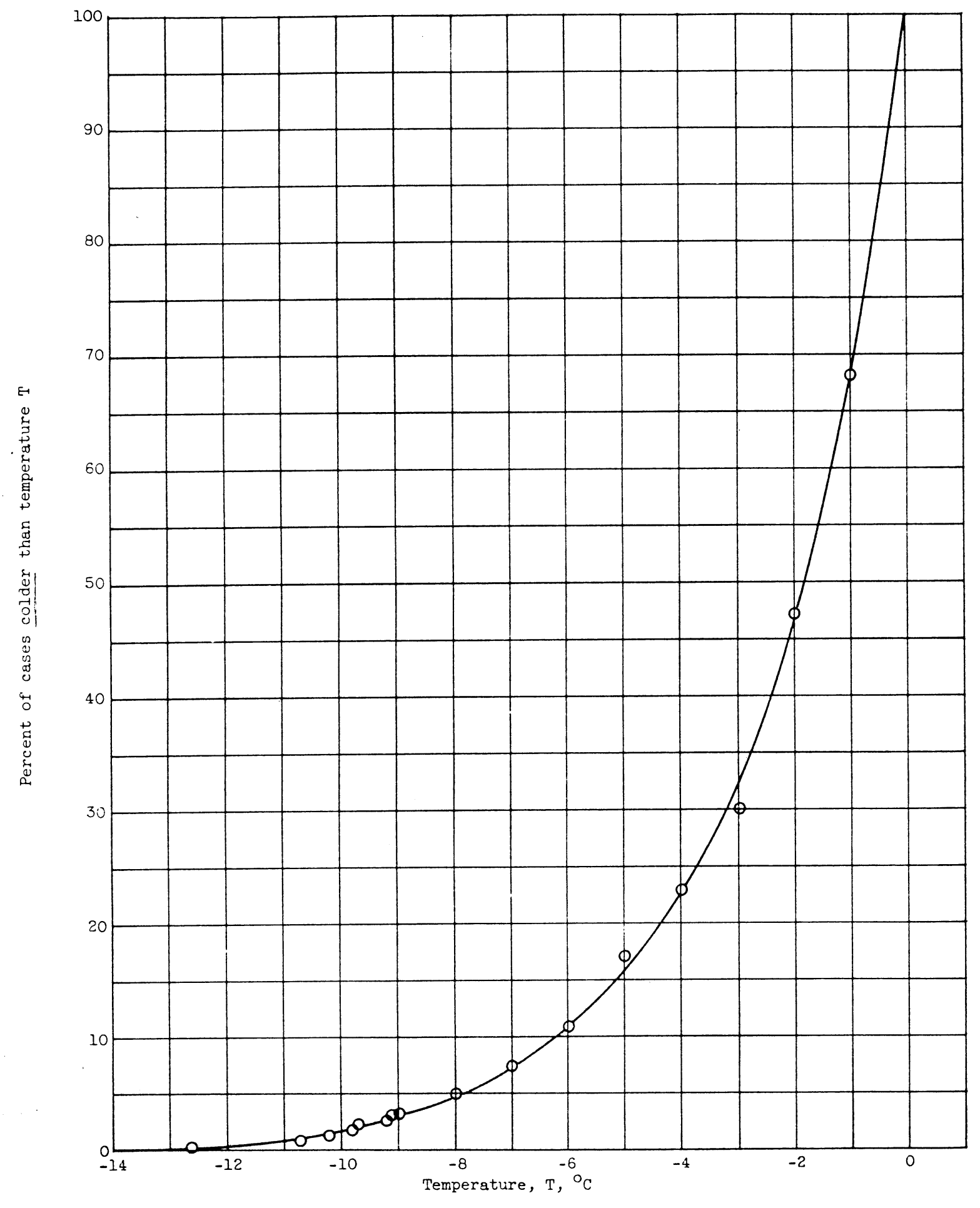

FIGURE 10. FREQUENCY DISTRIBUTION OF SURFACE AIR TEMPERATURE IN FREEZING RAIN IN THE NORTHEASTERN UNITED STATES [1] 


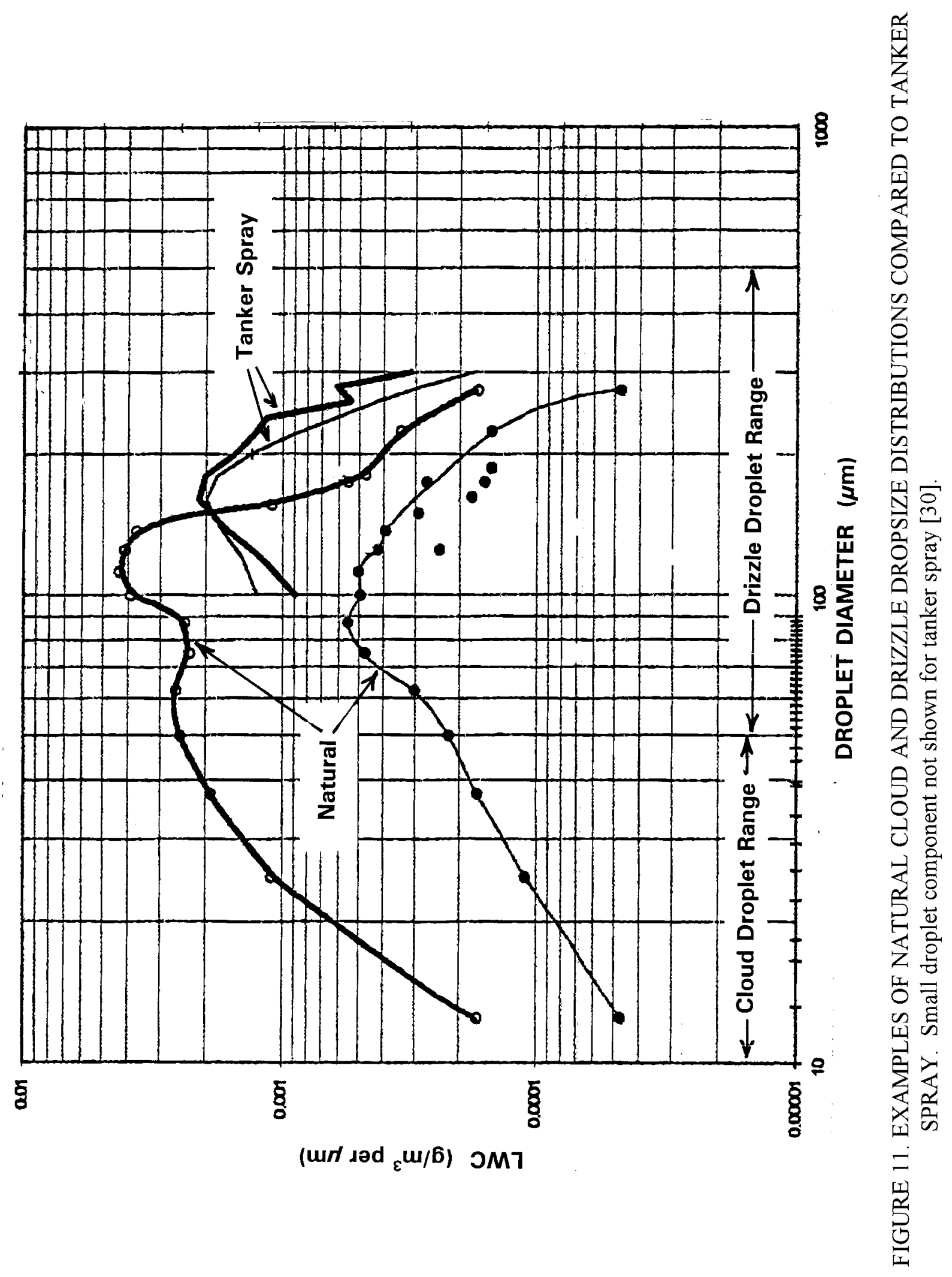




\section{TABLE 1. TYPES OF DATA AVAILABLE FOR FREEZING RAIN/DRIZZLE CONDITIONS}

$$
\text { ----Surface Observations---- }
$$

$\underline{\text { Direct Measurement }}$

Rain gauge (usually hourly)

Air temperature
Derived Information

Rain rate (and computed LWC), ranges and extremes, frequencies of occurrence.

Climatology of ZR/ZL conditions: geographic distribution, frequencies of occurrence, severity of conditions, duration of rainfall episodes.

Climatology of ZR/ZL conditions:

Temperature ranges and extremes, Temperature frequencies of occurrence.

----Radiosonde (Balloon) Observations----

Direct Measurement

Air temperature

Humidity

Wind speed \& direction

\section{Derived Information}

Climatology of Freezing Layers:

(ranges and frequencies of occurrence of:)

Heights and depths (thicknesses),

Minimum temperatures in the layers.

Cloud Layers.

Windshear and turbulence

----Instrumented Aircraft----

Direct Measurement

Droplet sizes

Icing rate

LWC
Derived Information

LWC, MVD

Icing rate, severity

LWC 


\section{TABLE 2. STATISTICS ON TYPE OF FREEZING PRECIPITATION AND} ACCOMPANYING VERTICAL TEMPERATURE STRUCTURE AT SELECTED LOCATIONS. (Listed in order of decreasing frequency of ZR and increasing frequency of $\mathrm{ZL}$ at the locations.)

\begin{tabular}{|c|c|c|c|c|c|c|c|}
\hline \multirow[b]{2}{*}{$\underline{\text { Location }}$} & \multicolumn{3}{|c|}{ Precipitation Type $^{1}$} & \multicolumn{4}{|c|}{ Temperature Structure Types ${ }^{2}$} \\
\hline & $\mathrm{ZR}(\%)$ & $\underline{\mathrm{ZL}(\%)}$ & $+\mathrm{IP}(\%)$ & $\underline{A(\%)}$ & $\underline{\mathrm{B}(\%)}$ & $\underline{\mathrm{C}(\%)}$ & Other $(\%)$ \\
\hline IAD & 84 & 5 & 11 & 21 & 47 & 0 & 32 \\
\hline BUF & 53 & 47 & 21 & 32 & 32 & 36 & 0 \\
\hline PIA & 47 & 53 & 21 & 26 & 32 & 37 & 5 \\
\hline JFK & 30 & 40 & 60 & 40 & 30 & 30 & 0 \\
\hline MAF & 26 & 74 & 5 & 11 & 68 & 21 & 0 \\
\hline GRB & 21 & 79 & 31 & 11 & 16 & 68 & 5 \\
\hline $\mathrm{CHI}$ & 20 & 80 & 20 & 30 & 40 & 30 & 0 \\
\hline $\mathrm{DEN}$ & 0 & 100 & 50 & 0 & 17 & 83 & 0 \\
\hline
\end{tabular}

\footnotetext{
${ }^{1}$ Note: These columns distinguish between freezing rain (ZR) and freezing drizzle (ZL), and list the percentage of cases where one or the other was reported in the surface observations at or near the release time of the radiosonde balloon. The column headed "+IP" gives the percentage of cases in which light snow or ice pellets were reported along with ZR or ZL.

${ }^{2}$ Definitions of the temperature structure types.

Code Explanation

A Classic textbook case of ZR (cold surface layer overrun by warm layer aloft, snowing cloud above warm layer, with melting layer (and snow cloud base) at the $0^{\circ} \mathrm{C}$ crossing at top of warm layer).

B Classic textbook temperature profile as above, but precipitation apparently originating in the low cloud layer-i.e., the upper cloud layer is absent or is not precipitating (not extending down to the $0^{\circ} \mathrm{C}$ level at the top of the warm layer).

C Cold layer only—no warm layer present; ZL apparently forming by "warm rain" or coalescence process.
} 


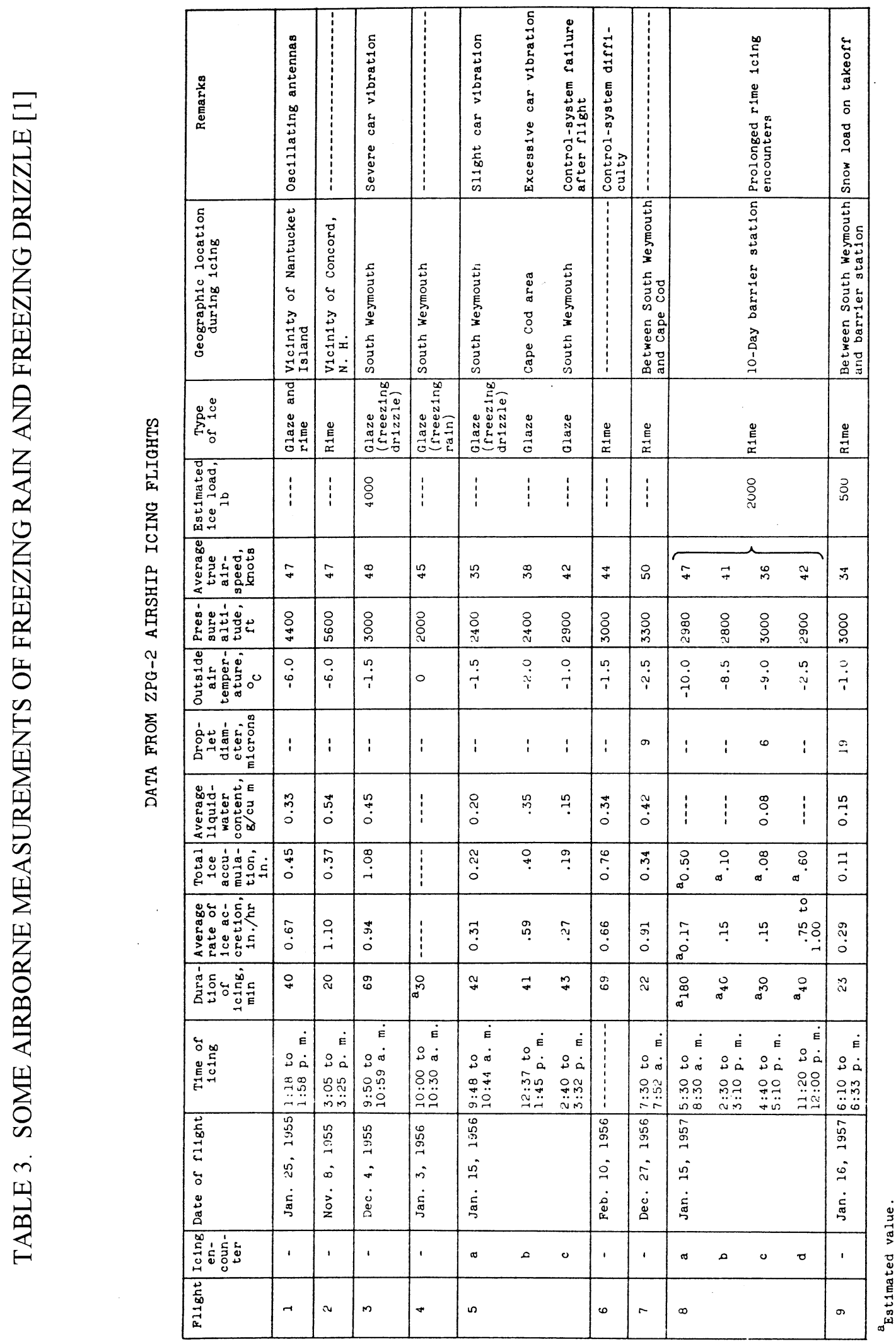


TABLE 4. AVAILABLE FREEZING RAIN DATA FROM UNIVERSITY OF NORTH DAKOTA INSTRUMENTED AIRCRAFT

\begin{tabular}{|c|c|c|c|c|c|c|}
\hline \multirow[b]{2}{*}{ Date } & \multirow[b]{2}{*}{$\underline{\text { Loc }}$} & \multirow{2}{*}{$\begin{array}{l}\text { Flight } \\
\text { Phase }\end{array}$} & \multirow{2}{*}{$\begin{array}{c}\text { AGL } \\
\text { Altitude } \\
\text { (1000's Ft) }\end{array}$} & \multicolumn{2}{|c|}{ 1DP Probe } & \multirow[b]{2}{*}{$\frac{\text { Temp }}{\left({ }^{\circ} \mathrm{C}\right)}$} \\
\hline & & & & $\frac{\text { LWC }}{\left(\mathrm{g} / \mathrm{m}^{3}\right)}$ & $\frac{\text { MVD }}{(\mathrm{mm})}$ & \\
\hline $3-17-87$ & GFK & Takeoff & $0-4$ & $0.1 \mathrm{avg}$. & $1-1.3$ & 0 to -2 \\
\hline $3-17-87$ & GFK & Climb out & $3-4$ & $0.1-0.2$ & $1-1.5$ & 0 to -4 \\
\hline $3-17-87$ & GFK & Climb out & $3-4$ & $0-0.1$ & $0.9-1.3$ & 0 to -4 \\
\hline $1-19-90$ & MKC & Landing & $0-1.4$ & $0.1-0.3$ & $1-1.5$ & 0 to -4 \\
\hline $1-19-90$ & MKC & Landing & $0.5-2$ & $0.3 \mathrm{avg}$. & $1-1.3$ & 0 to -4 \\
\hline $2-01-90$ & MKC & Takeoff & $0-2.5$ & $0.1-0.2$ & $1-1.3$ & 0 to -6 \\
\hline $2-01-90$ & MKC & Landing & $0-2.5$ & $0.1-0.2$ & $0.7-1.2$ & 0 to -5 \\
\hline $2-14-90$ & MKC & Takeoff & $0-4$ & $0.1-0.3$ & $0.8-1.5$ & 0 to -8 \\
\hline
\end{tabular}


TABLE 5. TEMPERATURES AND DEPTHS OF THE FREEZING RAIN OR FREEZING DRIZZLE LAYERS FROM RADIOSONDE MEASUREMENTS AT SELECTED LOCATIONS

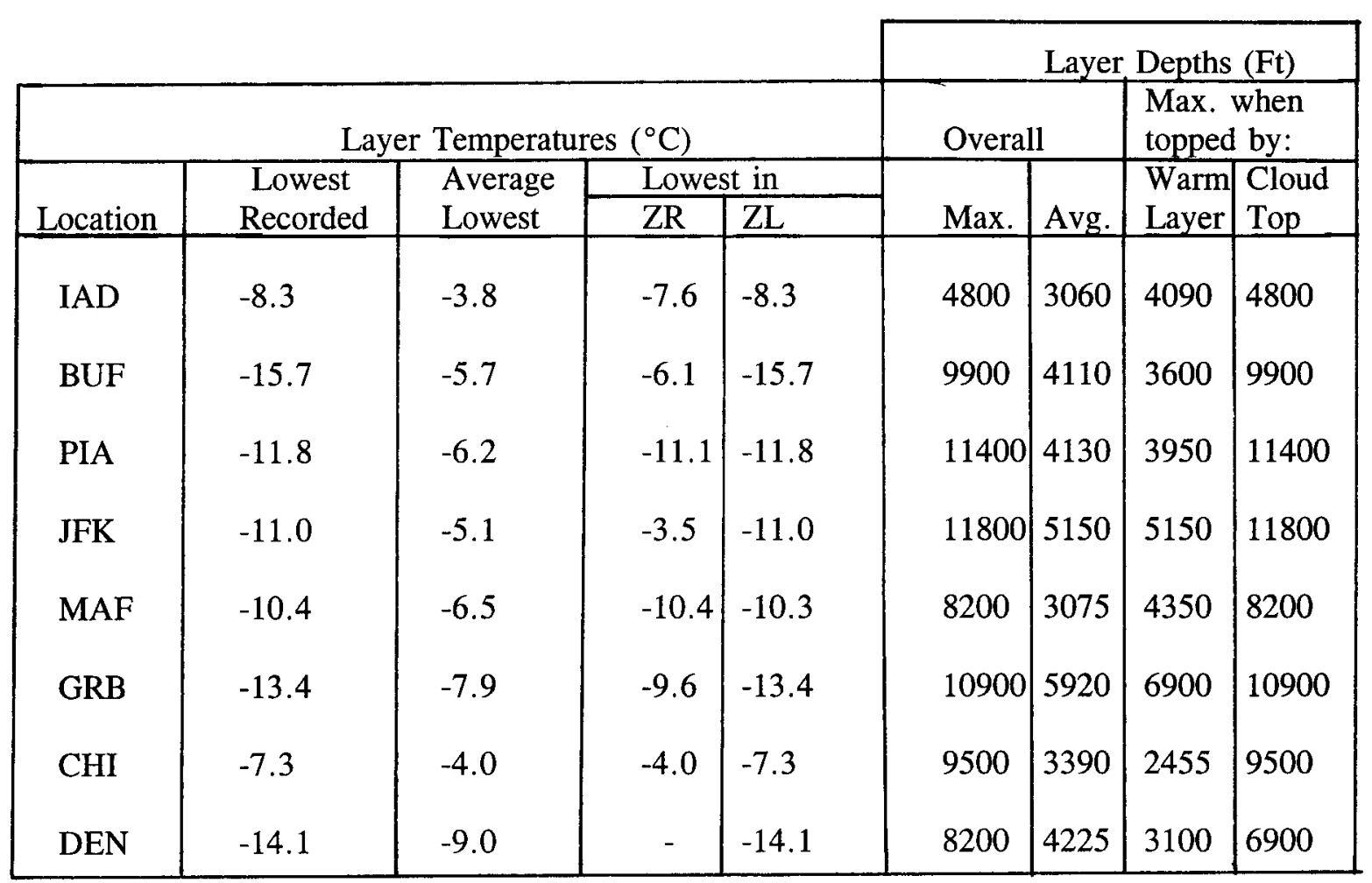


TABLE 6. EXAMPLES OF THE CONTRIBUTION OF "LARGE DROPLETS" TO THE OVERALL LWC AND MVD IN A NATURAL CLOUD CONTAINING

DRIZZLE [31]

\begin{tabular}{|c|c|c|c|c|c|c|}
\hline \multirow[b]{2}{*}{ Time } & \multirow{2}{*}{\multicolumn{2}{|c|}{ Droolet Di imeter Ranae }} & & \multicolumn{3}{|c|}{ Increases Contributed by each Droolet Range } \\
\hline & & & & CONC & $\begin{array}{l}W C_{3} \\
\left(a / m^{3}\right)\end{array}$ & $\begin{array}{l}\text { MOD } \\
(u n)\end{array}$ \\
\hline \multirow[t]{2}{*}{$1235: 58$} & $\begin{array}{r}3-45 \mu \mathrm{m} \\
45-200 \mu \mathrm{m} \\
200-300 \mu \mathrm{m}\end{array}$ & $\begin{array}{l}\text { (FSSP) } \\
(10-C) \\
(2 D-C)\end{array}$ & & $\begin{array}{r}172 \mathrm{~cm}^{-3} \\
198 \mathrm{l}^{-1} \\
81^{-1} \\
\end{array}$ & $\begin{array}{l}0.27 \\
0.09 \\
0.075 \\
\end{array}$ & $\begin{array}{r}16 \\
3 \\
2 \\
\end{array}$ \\
\hline & & & Totals: & $172 \mathrm{~cm}^{-3}$ & 0.435 & 21 \\
\hline \multirow[t]{2}{*}{$1236: 17$} & $\begin{array}{r}3-45 \mu \mathrm{m} \\
45-200 \mu \mathrm{m} \\
200-300 \mu \mathrm{m}\end{array}$ & $\begin{array}{l}(F S S P) \\
(1 D-C) \\
(2 D-C)\end{array}$ & & $\begin{array}{r}183 \mathrm{~cm}^{-3} \\
249 \mathrm{l}^{-1} \\
4 \mathrm{l}^{-1} \\
\end{array}$ & $\begin{array}{l}0.31 \\
0.09 \\
0.021 \\
\end{array}$ & $\begin{array}{r}19 \\
3.5 \\
0.5 \\
\end{array}$ \\
\hline & & & Totals: & $183 \mathrm{~cm}^{-\hat{\jmath}}$ & 0.42 & 23 \\
\hline \multirow[t]{2}{*}{$1236: 27$} & $\begin{array}{r}3-45 \mu \mathrm{m} \\
45-200 \mu \mathrm{m} \\
200-300 \mu \mathrm{m}\end{array}$ & $\begin{array}{l}(F S S P) \\
(1 D-C) \\
(2 D-C)\end{array}$ & & $\begin{array}{r}191 \mathrm{~cm}^{-3} \\
4191^{-1} \\
41^{-1} \\
\end{array}$ & $\begin{array}{l}0.25 \\
0.14 \\
0.025 \\
\end{array}$ & $\begin{array}{r}22 \\
5 \\
1 \\
\end{array}$ \\
\hline & & & Totals: & $191 \mathrm{~cm}^{-3}$ & 0.42 & 28 \\
\hline \multirow[t]{2}{*}{$1236: 59$} & $\begin{array}{r}3-45 \mu \mathrm{m} \\
45-200 \mu \mathrm{m} \\
200-300 \mu \mathrm{m}\end{array}$ & $\begin{array}{l}(F S S P) \\
(1 D-C) \\
(2 D-C) .\end{array}$ & & $\begin{array}{c}205 \mathrm{~cm}^{-3} \\
2661^{-1} \\
0\end{array}$ & $\begin{array}{l}0.13 \\
0.03 \\
0 \\
\end{array}$ & $\begin{array}{r}30 \\
7 \\
0 \\
\end{array}$ \\
\hline & & & Totals: & $205 \mathrm{~cm}^{-3}$ & 0.16 & 37 \\
\hline \multirow[t]{2}{*}{ 1237:06 } & $\begin{array}{r}3-45 \mu \mathrm{m} \\
45-200 \mu \mathrm{m} \\
200-300 \mu \mathrm{m}\end{array}$ & $\begin{array}{l}(F S S P) \\
(1 D-C) \\
(2 D-C)\end{array}$ & & $\begin{array}{c}168 \mathrm{~cm}^{-3} \\
1321^{-1} \\
0\end{array}$ & $\begin{array}{l}0.23 \\
0.02 \\
0 \\
\end{array}$ & $\begin{array}{r}28 \\
3 \\
0 \\
\end{array}$ \\
\hline & & & Totals: & $168 \mathrm{~cm}^{-3}$ & 0.25 & 31 \\
\hline
\end{tabular}


TABLE 7. PROPOSED LWC VERSUS DROPSIZE REPORTING SCHEME FOR DRIZZLE AND FREEZING RAIN

\section{Rule: Show or Specify LWC in Five Standardized Dropsize Intervals over an Appropriate Dropsize Range.}

\section{Advantages:}

- Easy to use and understand.

- Easy to specify test or design requirements: e.g., meet or exceed specified minimum LWC's for each size interval.

- Easy to compare measurements and requirements.

- Avoids the ambiguity of MVD or other single-number characterizations.

- Independent of any particular droplet probe.

Examples for Data Reporting, using the proposed scheme:

(The droplet concentrations are optional and are shown here for illustration purposes.)

\begin{tabular}{|c|c|c|c|c|c|c|}
\hline \multicolumn{7}{|c|}{ Drizzle } \\
\hline \multirow{2}{*}{$\begin{array}{l}\text { PROPOSED } \\
\text { STANDARD } \\
\text { SIZE } \\
\text { INTERVALS }\end{array}$} & \multicolumn{2}{|c|}{$\begin{array}{l}\text { Canada AES } \\
(3-14-92)\end{array}$} & \multicolumn{2}{|c|}{$\begin{array}{c}\text { U. Wyoming } \\
(3-8-94)\end{array}$} & \multicolumn{2}{|c|}{$\begin{array}{l}\text { USAF Tanker } \\
(12-18-94)\end{array}$} \\
\hline & $\begin{array}{l}\text { CONC } \\
\text { (no./1tr) }\end{array}$ & $\begin{array}{l}D W C \\
\left(\mathrm{~g} / \mathrm{m}^{3}\right)\end{array}$ & $\begin{array}{l}\text { CONC } \\
\text { (no./1tr) }\end{array}$ & $\begin{array}{l}D W C \\
\left(\mathrm{~g} / \mathrm{m}^{3}\right)\end{array}$ & $\begin{array}{l}\text { CONC } \\
\text { (no./1tr) }\end{array}$ & $\begin{array}{l}D W C \\
\left(\mathrm{~g} / \mathrm{m}^{3}\right)\end{array}$ \\
\hline $\begin{array}{l}50-100 \mu \mathrm{m} \\
0.1-0.2 \mathrm{~mm} \\
0.2-0.3 \mathrm{~mm} \\
0.3-0.4 \mathrm{~mm} \\
0.4-0.5 \mathrm{~mm}\end{array}$ & $\begin{array}{l}1.7 \\
1.4 \\
0.6 \\
0.08\end{array}$ & $\begin{array}{l}0.003 \\
0.010 \\
0.012 \\
0.003 \\
\end{array}$ & $\begin{array}{l}120 \\
20 \\
1.2 \\
0 \\
0\end{array}$ & $\begin{array}{l}0.021 \\
0.035 \\
0.010 \\
0 \\
0 \\
\end{array}$ & $\begin{array}{c}360 \\
100 \\
11 \\
0.4 \\
0\end{array}$ & $\begin{array}{l}0.065 \\
0.173 \\
0.093 \\
0.009 \\
0 \\
\end{array}$ \\
\hline Total LWC's: & & 0.028 & & 0.066 & & 0.34 \\
\hline
\end{tabular}

\section{Freezing Rain}

\begin{tabular}{|l|ll|}
\hline \multirow{2}{*}{$\begin{array}{l}\text { PROPOSED } \\
\text { STANDARD } \\
\text { SIZE } \\
\text { INTERVALS }\end{array}$} & \multicolumn{2}{|c|}{$\begin{array}{l}\text { Univ. } \\
\text { NTorth Dakota } \\
(2-14-90)\end{array}$} \\
\cline { 2 - 3 } & $\begin{array}{l}\text { CONC } \\
(\text { no./1tr })\end{array}$ & $\begin{array}{c}\text { RWC } \\
\left(\mathrm{g} / \mathrm{m}^{3}\right)\end{array}$ \\
\hline $0.5-1 \mathrm{~mm}$ & 0.4 & 0.069 \\
$1-1.5 \mathrm{~mm}$ & 0.03 & 0.036 \\
$1.5-2 \mathrm{~mm}$ & 0.01 & 0.035 \\
$2-3 \mathrm{~mm}$ & 0.002 & 0.012 \\
$3-4 \mathrm{~mm}$ & 0.000 & $\underline{0.000}$ \\
Total LWC's: & & 0.15 \\
\hline
\end{tabular}


TABLE 8. POSSIBLE FIRST-PRIORITY DESIGN VARIABLES (tentative values inserted)

\begin{tabular}{|c|c|c|c|c|c|c|}
\hline \multicolumn{7}{|c|}{......Freezing Rain..... } \\
\hline Variable & \multicolumn{2}{|c|}{$\begin{array}{l}\text { Known } \\
\text { or Est imated } \\
\text { Range }\end{array}$} & \multicolumn{2}{|l|}{$\begin{array}{l}\text { Representative } \\
\text { Value }\end{array}$} & \multicolumn{2}{|c|}{$\begin{array}{l}\text { Source } \\
\text { of Data }\end{array}$} \\
\hline $\operatorname{RHC}\left(\mathrm{g} / \mathrm{m}^{3}\right)$ & \multicolumn{2}{|c|}{0 to 0.3} & \multicolumn{2}{|l|}{0.15} & \multicolumn{2}{|c|}{$a, b, c, d$} \\
\hline Dropsize (mm) & \multicolumn{2}{|c|}{0.25 to 4 dia. } & \multicolumn{2}{|l|}{ (see below) } & \multicolumn{2}{|c|}{$a, c, d$} \\
\hline Temperature $\left({ }^{\circ} \mathrm{C}\right)$ & \multicolumn{2}{|c|}{0 to -12} & \multicolumn{2}{|c|}{$\begin{array}{l}-2 \text { (at ground level) } \\
-7 \text { (at } 3300 \mathrm{Ft} \mathrm{AGL)}\end{array}$} & \multicolumn{2}{|c|}{ b.d } \\
\hline $\begin{array}{c}\text { Altitude (AGL) } \\
\mathrm{Ft} . \\
\mathrm{km}\end{array}$ & \multicolumn{2}{|c|}{$\begin{array}{l}0 \text { to } 6900 \\
0 \text { to } 2\end{array}$} & \multicolumn{2}{|l|}{$\begin{array}{l}0 \text { to } 3300 \\
0 \text { to } 1\end{array}$} & \multicolumn{2}{|c|}{$\begin{array}{l}\text { a.d } \\
\text { a.d }\end{array}$} \\
\hline \multicolumn{7}{|c|}{ Exposure: Use representative time below $7000 \mathrm{Ft}$ AGL during approach. } \\
\hline \multicolumn{7}{|c|}{$\begin{array}{l}\text { Representative LWC Distribution vs. Dropsize } \\
\text { (in the freezing rain dropsize range only) }\end{array}$} \\
\hline \multicolumn{2}{|c|}{ Dropsize Interval $(\mathrm{mm})$ : } & $0.5-1$ & $1 \cdot 1.5$ & \multicolumn{2}{|c|}{$1.5-2$} & $2 \cdot 3$ \\
\hline \multirow{2}{*}{\multicolumn{2}{|c|}{ Incremental RWC $\left(\mathrm{g} / \mathrm{m}^{3}\right)$ : }} & 0.4 & 0.03 & & & 0.002 \\
\hline & & 0.07 & 0.04 & & & 0.01 \\
\hline
\end{tabular}

\begin{tabular}{|c|c|c|c|c|c|c|c|}
\hline \multicolumn{8}{|c|}{.....Freezing Drizzle..... } \\
\hline Variable & \multicolumn{2}{|c|}{\begin{tabular}{|l} 
Known \\
or Estimated \\
Range
\end{tabular}} & \multicolumn{2}{|l|}{$\begin{array}{l}\text { Representative } \\
\text { Value }\end{array}$} & \multicolumn{3}{|c|}{$\begin{array}{l}\text { Source } \\
\text { of Data }\end{array}$} \\
\hline $\operatorname{DWC}\left(\mathrm{g} / \mathrm{m}^{3}\right)$ & \multicolumn{2}{|c|}{0 to $<0.3$} & \multicolumn{2}{|l|}{0.08} & \multicolumn{3}{|c|}{$e, d$} \\
\hline Dropsize $(\mu \mathrm{m})$ & \multicolumn{2}{|c|}{50 to 500 dia. } & \multicolumn{2}{|l|}{ (see below) } & \multicolumn{3}{|c|}{ f.d } \\
\hline Temperature $\left({ }^{\circ} \mathrm{C}\right)$ & \multicolumn{2}{|l|}{0 to -15} & \multicolumn{2}{|c|}{$\begin{array}{l}-2 \text { (at ground level) } \\
-2 \text { to }-10 \text { (at } 3.5 \mathrm{~km} \mathrm{AGL} \text { ) }\end{array}$} & \multicolumn{3}{|c|}{$\begin{array}{l}d \\
d\end{array}$} \\
\hline $\begin{array}{c}\text { Altitude (AGL) } \\
\mathrm{Ft} . \\
\mathrm{km}\end{array}$ & \multicolumn{2}{|c|}{$\begin{array}{l}0 \text { to } 17,000 \\
0 \text { to } 5\end{array}$} & $\begin{array}{l}0 \text { to } 15.000 \\
0 \text { to } 4\end{array}$ & & \multicolumn{3}{|c|}{$\begin{array}{l}\text { d } \\
\text { d }\end{array}$} \\
\hline \multicolumn{8}{|c|}{ Exposure: Use holding time. } \\
\hline \multicolumn{8}{|c|}{$\begin{array}{c}\text { Representative LWC Distribution vs. Dropsize } \\
\text { (in the drizzle dropsize range only): }\end{array}$} \\
\hline \multicolumn{2}{|c|}{ Dropsize Interval $(\mu \mathrm{m})$ : } & $50-100$ & $100 \cdot 200$ & \multicolumn{2}{|c|}{$200-300$} & $300-400$ & $400-500$ \\
\hline \multicolumn{2}{|c|}{ Droplets per liter: } & 120 & 20 & \multicolumn{2}{|c|}{1.2} & 0.6 & 0.08 \\
\hline \multicolumn{2}{|c|}{ Incremental DWC $\left(\mathrm{g} / \mathrm{m}^{3}\right)$ : } & 0.021 & 0.035 & \multicolumn{2}{|c|}{0.010} & 0.012 & 0.003 \\
\hline
\end{tabular}

\footnotetext{
Sources of Data:

$a=$ Ref. 13, 25 (British Isles)

$b=$ Ref. 1. 27 (New England region of U.S.A.)

$\mathrm{c}=$ Ref. $26 \quad$ (centrai U.S.A.)

$d=$ present study (central and eastern U.S.A.)

e $=$ Ref. 5

$f=$ Ref. 14,31
} 